\title{
Current perspective on production and applications of microbial cellulases: a review
}

Nisha Bhardwaj ${ }^{1,2 \dagger}$, Bikash Kumar $^{1 \dagger}$, Komal Agrawal $^{1}$ and Pradeep Verma ${ }^{1 *}$ (1)

\begin{abstract}
The potential of cellulolytic enzymes has been widely studied and explored for bioconversion processes and plays a key role in various industrial applications. Cellulase, a key enzyme for cellulose-rich waste feedstock-based biorefinery, has increasing demand in various industries, e.g., paper and pulp, juice clarification, etc. Also, there has been constant progress in developing new strategies to enhance its production, such as the application of waste feedstock as the substrate for the production of individual or enzyme cocktails, process parameters control, and genetic manipulations for enzyme production with enhanced yield, efficiency, and specificity. Further, an insight into immobilization techniques has also been presented for improved reusability of cellulase, a critical factor that controls the cost of the enzyme at an industrial scale. In addition, the review also gives an insight into the status of the significant application of cellulase in the industrial sector, with its techno-economic analysis for future applications. The present review gives a complete overview of current perspectives on the production of microbial cellulases as a promising tool to develop a sustainable and greener concept for industrial applications.
\end{abstract}

Keywords: Cellulase, Cellulose, Mechanism, Biorefinery, Techno-economic aspects

\section{Introduction}

The continuous increase in worldwide industrialization has made researchers find economical ways to fulfill the growing demand. Industries like automobiles, textiles, animal feed, detergent, paper, health care needs, food processing, manure, wine making, and waste management have shown a gradual increase in their demand. Hence, it is necessary to fulfill these requirements without affecting the economy or any harsh effects on the environment. All the industries require various parameters to be considered, such as the use of enzyme-based catalysis, biodegradable and cost-effective raw materials, and low risk of environmental effects (Ding et al. 2008).

\footnotetext{
*Correspondence: vermaprad@yahoo.com; pradeepverma@curaj.ac.in ${ }^{\dagger}$ Nisha Bhardwaj and Bikash Kumar contributed equally to this work

${ }^{1}$ Bioprocess and Bioenergy Laboratory, Department of Microbiology, Central University of Rajasthan, NH-8, Bandarsindri, Kishangarh, Ajmer, Rajasthan 305817, India

Full list of author information is available at the end of the article
}

Lignocellulosic biomass (LCB) obtained from agricultural and forestry industries can serve as suitable raw materials as they are abundantly available throughout the year (Hou et al. 2020; Pandey and Negi 2020; Verma et al. 2018; Zhao et al. 2019). Cellulose is the main polysaccharide of lignocellulosic plant biomass, its hydrolysis to glucose using enzymes comprises the synergy of three enzymes, i.e., endoglucanases (EC 3.2.1.4), exoglucanases or cellobiohydrolases (EC 3.2.1.91), and $\beta$-glucosidases (EC 3.2.1.21). The glycosidic bonds present in the cellulosic biomass are hydrolyzed randomly by endoglucanases in the crystalline and amorphous regions (Sharma et al. 2016; Teter et al. 2014), resulting in the oligosaccharides generation. These oligomers are cleaved by exoglucanases in the reducing and non-reducing ends to generate cellobiose which is further hydrolyzed by $\beta$-glucosidases to release sugar molecules such as glucose (Allardyce et al. 2010; Juturu and Wu 2014a, b). Although a massive amount of LCB is being used for 
various applications worldwide, many unused and partially hydrolyzed raw materials due to the high processing cost are gathering in the biosphere, causing pollution is under focus currently. It has been noticed that in most bioprocess-based industries, the cellulose bioconversion process from LCB is affected by microcrystalline structure of the cellulose-rich materials. Although plenty of conventional physical and chemical methods have been utilized to date for the pretreatment of these materials with interesting output, some secondary contamination was also observed, negatively affecting their utility. Therefore, microbial enzymes are a suitable alternative for increasing the effectiveness of cellulosic bioresources (Premalatha et al. 2015).

Since two decades, cellulase has gained enormous attention as an industrially important enzyme with a wide range of applications. Cellulases are utilized for the saccharification of cellulose which is the innermost component of the lignocellulosic plant biomass. This process of saccharification using cellulase results in the release of glucose that can further be converted to biofuel such as bioethanol by using ethanologenic microorganisms (Nguyen et al. 2018; Raj and Krishnan 2018). Similarly, cellulase and pectinase cocktails have shown better fruit juice extraction and clarification in the food processing industries. Recently, cellulase has been considered the 3rd most important industrial enzyme in the retail market worldwide (Oberoi et al. 2010). Hence, considering these facts, cellulase production has been considered as an important step for the economical use of renewable lignocellulose (raw materials) for the generation of value-added products such as ethanol, single-cell proteins, and other chemicals (Bhardwaj et al. 2019; Kumar et al. 2018). The production process of cellulase is quite expensive and contributes to $50 \%$ of the total hydrolysis cost. Therefore, lignocellulosic plant biomass can be considered as an economical raw material for cellulase production and other industrial by-products (Verma et al. 2011; Guldhe et al. 2017). The cellulolytic enzymes are primarily obtained from the microbial origin with noticeable enzymatic activity and stability variations, e.g., physical parameters like $\mathrm{pH}$ and temperature. Numerous bacteria, protozoans, fungi, animals, and plants have been reported for their ability to produce cellulases.

Hence, with the concern of high demand, the requirement of finding new microbial isolates by exploring different ecological habitats has become essential. The present review includes up-to-date exploration of cellulases, emphasizing the source, mechanism, and methods for enhanced cellulase production with high activity, specificity, and reusability. The review also gives insight into the major application of cellulase in

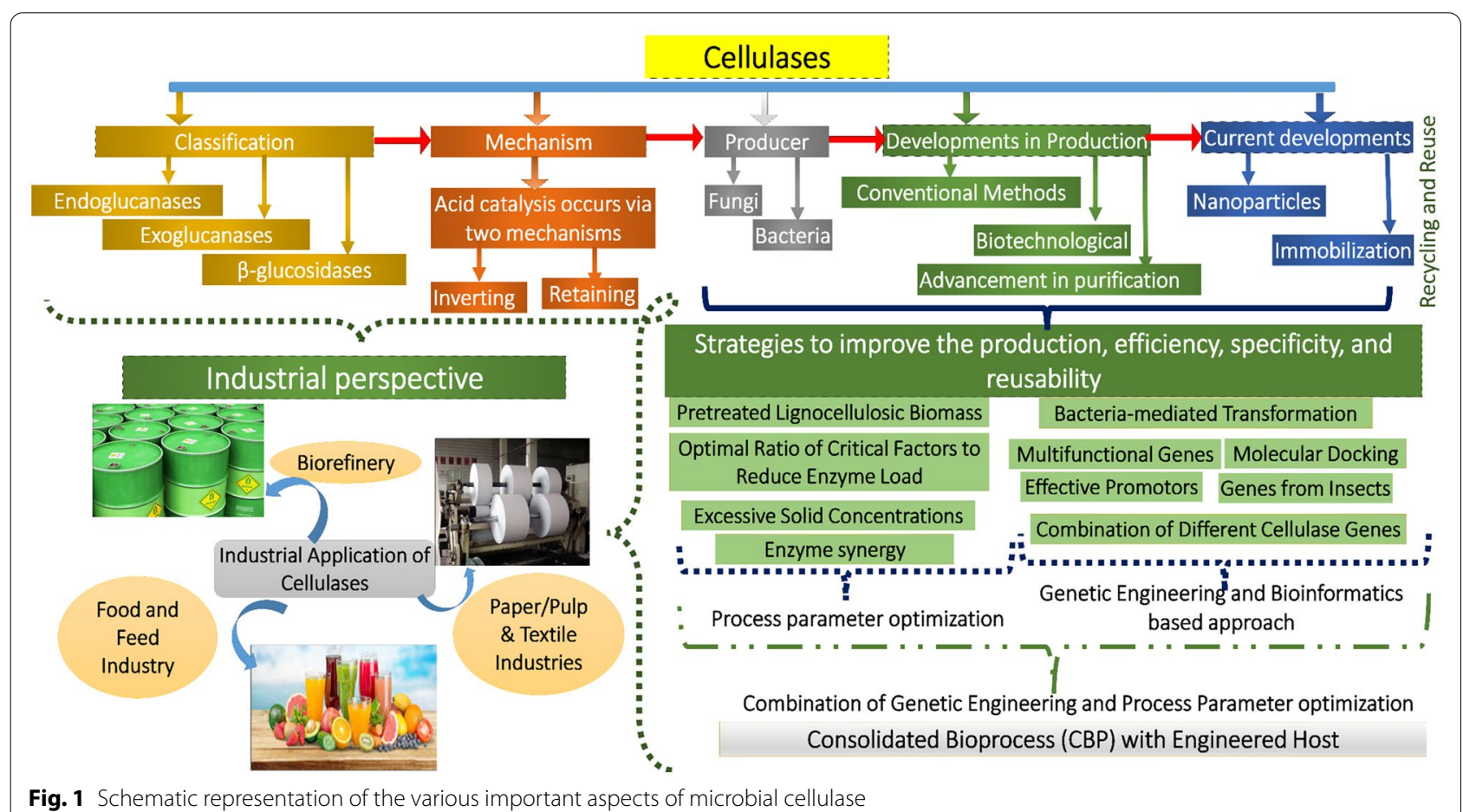

Fig. 1 Schematic representation of the various important aspects of microbial cellulase 
the industrial sector with its techno-economic analysis for future applications (Fig. 1).

\section{Classification and mechanism of action of cellulolytic enzymes}

Cellulolytic enzymes are mainly designated under three groups, first endoglucanases (EC 3.2.1.4) (1,4- $\beta$-D-glucan4-glucanohydrolase or carboxymethyl cellulase), second exoglucanases [Cellobiohydrolase (EC 3.2.1.91) and cellodextrinase (EC 3.2.1.74)] and third $\beta$-glucosidases (EC 3.2.1.21) (Hasunuma et al. 2013). All three cellulase groups consist of members in separate $\mathrm{GH}$ families based on the CAZy database classification (Lombard et al. 2014). The classification of cellulases is prepared according to the depolymerization stage of the targeting substrate. The glycosidic bonds present in crystalline and amorphous cellulose are randomly hydrolyzed by endoglucanases and lead to the production of oligomers with varying polymerization degrees (Sharma et al. 2016; Teter et al. 2014). However, Szijártó et al. (2008) have also experimentally proved that the EG is more active toward crystalline cellulose, whereas amorphous cellulose is prone to action by $\mathrm{CBH}$. After this $\beta$-1,4-glycosidic bonds present at the reducing and non-reducing ends of the oligomers are hydrolyzed by the exoglucanases and produce cellobiose which is degraded further to glucose by $\beta$-glucosidases (Hasunuma et al. 2013; Juturu and Wu 2014a, b). Some other critical enzymes that catalyze reversible phosphorolytic cleavage and epimerization are also grouped as part of the cellulase enzyme complex. Cellobiose phosphorylase or cellobiase (orthophosphate $\alpha$-D-glucosyl transferase, EC 2.4.1.20) catalyzes reversible phosphorolytic cleavage of cellobiose to glucose.
Cellodextrin phosphorylase (1,4- $\beta$-D-oligoglucan orthophosphate $\alpha$-D-glucosyl transferase, EC 2.4.1.49) catalyzes the conversion of cellodextrins (cellotriose to cellohexose) to glucose. Cellodextrin phosphorylase does not act on cellobiose. Cellobiose epimerase (EC 5.1.3.11) catalyzes the epimerization of disaccharides like cellobiose into 4-O- $\beta$-D-glucosylmannose (Sharma et al. 2016).

Additionally, the cellulase enzyme mixture also consists of other accessory proteins such as swollenin and lytic polysaccharide monooxygenase (Harris et al. 2014), facilitating the cellulose degradation. Trichoderma reesei protein called the exoproteome is a widely utilized cellulase producer at the industrial level that consists of two cellobiohydrolases (approximately $70 \%$ of total proteins), three types of endo-1,4- $\beta$-glucanases, one lytic polysaccharide monooxygenase, and one $\beta$-glucosidase (Bischof et al. 2016; Herpoël-Gimbert et al. 2008). The cellobiohydrolases are extensively suggested for their necessity in the effective degradation of type I crystalline cellulose (a major allomorph of plants crystalline cellulose Gusakov et al. 2007; Morozova et al. 2010; Szijártó et al. 2008). The enzymatic saccharification rate is reported to be effectively improved when the crystalline cellulose I is disrupted to other crystalline allomorphs (Chundawat et al. 2011; Igarashi et al. 2007; Szijártó et al. 2008).

The synergistic action of the cellulase enzyme complex controls the bioconversion of cellulose to glucose that can be explained in two steps (Fig. 2). The first step involves the action of exo- and endoglucanases that cause a reduction in the polymerization degree of cellulose in the stage of liquefaction and releases cellobiose. $\beta$-Glucosidase is involved in the second step that converts cellobiose into glucose (Maeda et al. 2013).

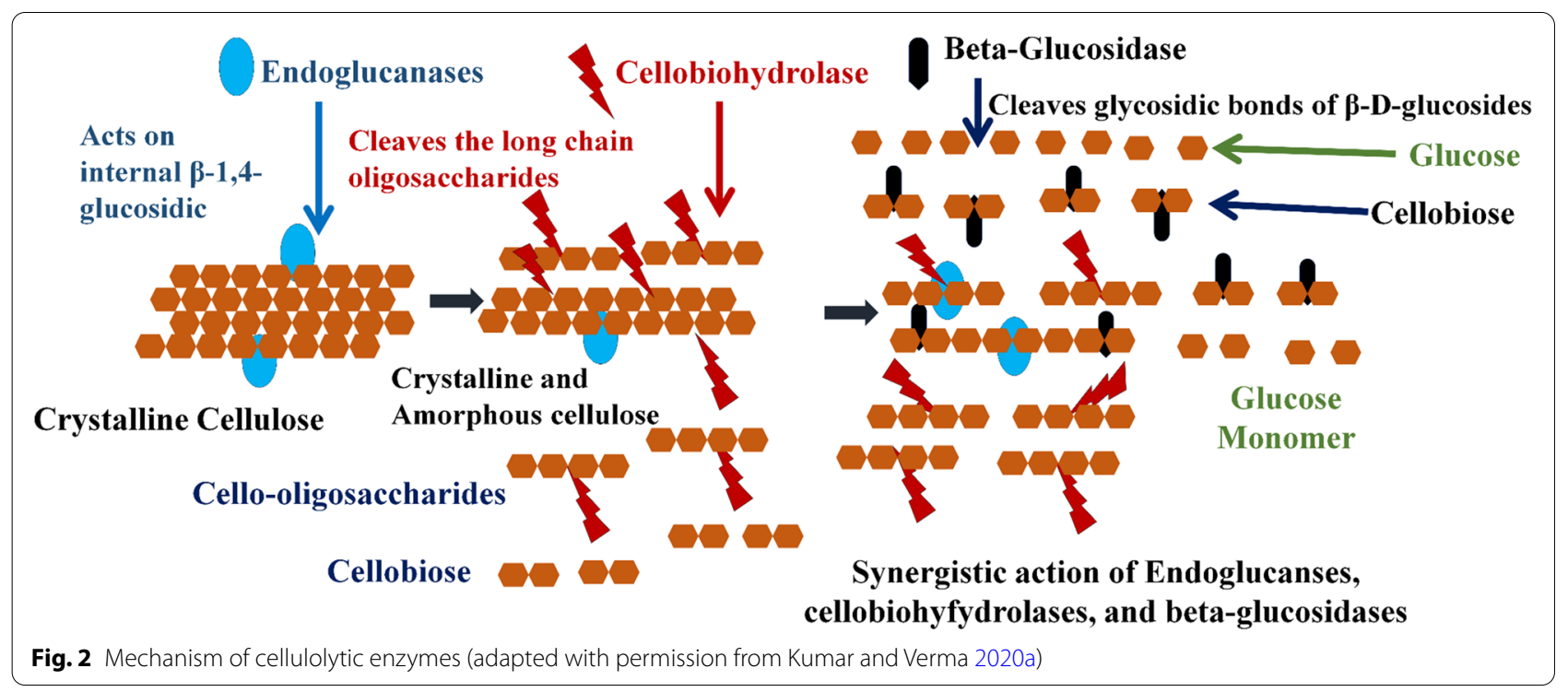


Similar to hydrolytic enzymes, a water molecule is inserted into the substrate by cellulases during a nucleophilic attack. All the three enzyme types, i.e., endoglucanases, exoglucanases, $\beta$-glucosidase shows synergistic action by the similar types of action mechanism known as acid catalysis. The acid catalysis occurs in two different mechanisms, i.e., inverting and retaining. The action pathway of cellulases mainly depends on the distance of the catalytic sites. During inverting mechanism, there is no enzyme-substrates complex formation throughout the reaction, and the hydrolysis process is directly achieved by sequential deprotonation. The carboxylic ends present in the amino acid residues are involved in the retaining mechanism acting as a nucleophilic base that attacks the glycosidic bond, breaks it, binds itself to an oligomeric fraction, and forms an enzyme-substrate complex (Ng and Cheung 2011; Qi 2017).

The cellulase adsorption onto the insoluble cellulose surface is vital for the effective hydrolysis process. The cellulose-binding domain is mainly responsible for adsorption (Linder and Teeri 1997). In fungal cellulases, the cellulose-binding domain mainly consists of 40 amino acids module kept in the CAZy database as carbohydratebinding module family 1 (CBM 1) (Boraston et al. 2004). The CBM 1 inactivation or removal in T. reesei cellobiohydrolase I (CBH I) has dramatically reduced its binding capacity and hydrolysis activity on crystalline cellulose (Amore et al. 2017; Cruys-Bagger et al. 2013; Reinikainen et al. 1992). In contrast, CBM 1 to CBM 1-lacking cellulases fusion can efficiently improve their hydrolysis activities on crystalline cellulose (Szijártó et al. 2008).

The cellulase enzymes structure and substrate binding mechanism vary from microorganism to microorganism (Juturu and Wu 2014a, b). Fungal and aerobic bacterial cellulases are released extracellularly from the cell as free molecules into the medium. On the other hand, in case of anaerobic bacterial cellulases it remains linked to the surface of the cell by forming a protein complex known as cellulosome (Doi and Kosugi 2004). Cellulases from aerobic microorganisms are found in different architecture involving two domains linked by a peptide. One is the cellulose-binding domain, and another acts as a catalytic site (Park et al. 2010). Several other structures with different functions can be found on the protein (Rabinovich et al. 2002).

\section{Overview of cellulolytic enzymes production}

Microorganisms such as bacteria and fungi are good producers of cellulolytic enzymes, although fungi were more suitable for cellulase producers due to their extracellular properties. Thus, continuous exploration in search of new microorganisms (Table 1) has become essential to favors industrial needs (Premalatha et al. 2015). On a commercial scale, several fungal and bacterial strains have been utilized to produce cellulases. Commercially, substrates such as cellulose or carboxymethyl cellulose (CMC) have been used to produce cellulase; however, are very costly. Thus, scientists attempted to replace this costly substrate with naturally occurring cellulose-rich biomass such as agricultural and forest residues (De Almeida et al. 2019; Crognale et al. 2019; Goldbeck et al. 2013).

\section{Utilization of pure cellulose as a substrate for cellulase production}

Pure cellulose obtained from microbes and biomass processing can be used as substrates to produce cellulases (Azeredo et al. 2019; Thulluri et al. 2021). Kumar et al. (2018) demonstrated the utilization of commercially available cellulose (CMC) as the substrate for cellulase production using fungal strain Schizophyllum commune

Table 1 Cellulases production potential of microbial strains by utilizing plant residues as carbon sources

\begin{tabular}{|c|c|c|c|}
\hline Microorganisms & Carbon sources & Yield & References \\
\hline Aspergillus niger & Corn stover & $6.28 \mathrm{U} / \mathrm{mL}$ & Xue et al. (2020) \\
\hline Rhizopus oryzae UC2 & Oil palm frond leaves & CMCase $94.68 \mathrm{U} / \mathrm{g}$, FPase $25.46 \mathrm{U} / \mathrm{g}$, $\beta$-glucosidase $145.47 \mathrm{U} / \mathrm{g}$ & Ezeilo et al. (2019b) \\
\hline Trichoderma asperellum UC1 & Raw oil palm frond leaves & $\begin{array}{l}\text { CMCase } 136.16 \mathrm{IU} / \mathrm{g}, \text { FPase } 26.03 \mathrm{U} / \mathrm{g}, \beta \text {-glucosidase } 130.09 \mathrm{lU} / \mathrm{g} \text {, } \\
\text { xylanase activity } 255.01 \mathrm{U} / \mathrm{g}\end{array}$ & Ezeilo et al. (2019a) \\
\hline Trichoderma harzianum & Rice straw & Cellulase $12.7 \mathrm{U} / \mathrm{g}$, xylanase $110.7 \mathrm{U} / \mathrm{g}$ & Syuan et al. (2018) \\
\hline Trichoderma harzianum & Domestic wastewater & FPase $5.4 \mathrm{U} / \mathrm{mL}$, CMCase $8.2 \mathrm{U} / \mathrm{mL}$ & Libardi et al. (2017) \\
\hline Cellulomonas uda NCIM 2353 & Waste date seeds & $175.96 \mathrm{IU} / \mathrm{mL}$ & Swathy et al. (2019) \\
\hline A. thermoaerophilus, B. borstelensis & Sugarcane bagasse & 22.18 and $33.3 \mathrm{IU} / \mathrm{mL}$ of endoglucanase & Ejaz et al. (2020) \\
\hline Aspergillus japonicus URM5620 & Passiflora edulis peel waste & Total cellulase FPase $(1.2 \mathrm{U} / \mathrm{mL})$ endoglucanase CMCase $1.7 \mathrm{U} / \mathrm{mL}$ & Silva et al. (2019) \\
\hline Bacillus velezensis ASN1 & Waste office paper & $2.42 \mathrm{U} / \mathrm{mL}$ & Nair et al. (2018) \\
\hline Trichoderma reesei & Duckweed (Lemna minor) & $6.5 \mathrm{FPU} / \mathrm{mL}$ & Li et al. (2019) \\
\hline $\begin{array}{l}\text { Trichoderma reesei NCIM } 1186, \\
\text { Penicillium citrinum NCIM } 768\end{array}$ & Wheat bran & $6.71 \mathrm{FPU} / \mathrm{gds}$ & Lodha et al. (2020) \\
\hline
\end{tabular}


NAIMCC-F-03379. They compared it with the utilization of different LCB as a substrate. The study showed that wheat bran and CMC showed comparable CMCase and FPase activity. In contrast, all other biomass, i.e., rice straw, rice husk, wheat straw, and sugarcane bagasse, showed poor cellulase activity as compared to commercial cellulose (Kumar et al. 2018). Although cellulase enzyme preparation from fungi is in trend, cellulase-producing bacteria have attracted significant attention due to their strong adaptability (Sadhu et al. 2013a). A total of 10 cellulase-producing bacterial strains were reported from Min pig manure, with the best enzyme producing ability in Bacillus velezensis ( $\mathrm{Li}$ et al. 2020). Gupta and Samant (2012) demonstrated the application of Whatman filter paper rich in cellulose as a substrate for cellulase production utilized by cellulolytic bacteria. The obtained cellulolytic enzyme was then applied for simultaneous saccharification and fermentation (SSF) for efficient ethanol generation ability. Similarly, Li et al. (2009) demonstrated recombinant expression of thermostable cellobiohydrolase gene from Chaetomium thermophilum. Pichia pastoris efficiently utilized cellulose-rich microcrystalline cellulose for cellulase production. The purified enzyme was found to be thermotolerant $\left(60^{\circ} \mathrm{C}\right)$ and stable at acidic $\mathrm{pH}$ (5.0) and showed high saccharification of cellulose substrates such as filter paper.

Although the production of cellulase utilizing LCB as a substrate is lower than that of a pure cellulose-containing culture medium. But the variable structural complexities and low solubility of the pure crystalline cellulose can limit its application as a substrate for cellulase production (Lynd et al. 2002). The commercially available cellulose derivatives are soluble and can result in enhanced cellulase enzyme production in a shorter duration due to the non-requirement of time for overcoming recalcitrance lignin (Chukwuma et al. 2020; Kucharska et al. 2018). But the cost of these derivatives compensates for the time required while using the LCB as substrate. Also, the application LCB helps in the production of other auxiliary enzymes such as hemicellulases, laccases, and LPMOs (Lopes et al. 2018; Obeng et al. 2017). Thus, selecting a suitable biomass/substrate is critical to increasing the potential of enzyme cocktail for saccharification in consolidated bioprocessing in lignocellulosic biorefinery (Østby et al. 2020).

\section{Utilization of LCB as a substrate for cellulase production}

In a study by Marques et al. (2018), a total of fourteen (14) endophytic fungal strains were randomly chosen and prospected for cellulases and xylanases production by solid-state fermentation (SsF). Initially, fungi were cultivated in a mixture $(1: 1 \mathrm{w} / \mathrm{w})$ of sugarcane bagasse and wheat bran for 7 days at $28{ }^{\circ} \mathrm{C}$. In the initial screening, a total of four (4) fungi, i.e., Cladosporium cladosporioides PAJ 03, Phomopsis stipata SC 04, Trichoderma viridae PAJ 01, and Botryosphaeria sp. AM 01 shown endoglucanase activity in a range of $42.79 \pm 1.6 \mathrm{U} / \mathrm{g}$ to $88.51 \pm 1.0 \mathrm{U} / \mathrm{g}$. The other four (4) endophytic fungi, i.e., Saccharicola sp. EJC 04, Paecilomyces sp. SF 021, Ustilaginoidea sp. CV 04, and Ustilaginoidea sp. XYA 04 exhibited $\beta$-glucosidase activity in a range of $21.72 \pm 3.05 \mathrm{U} / \mathrm{g}$ to $51.56 \pm 2.7 \mathrm{U} / \mathrm{g}$. Among these fungal strains, maximum xylanase and $\beta$-xylosidase activity of 694.33 and $4.87 \mathrm{U} / \mathrm{g}$ was reported in fungi, P. stipata SC 04, and Botryosphaeria sp. AM 01, respectively. Further, these eight (8) endophytic fungi were grown in media substituted with lignocellulosic substrates, i.e., 1:1 (w/w) of cotton seed meal and wheat bran. Maximum endoglucanase and $\beta$-glucosidase activities of $184.74 \pm 6.0$ and $92.28 \pm 9.57 \mathrm{U} / \mathrm{g}$ were observed with Botryosphaeria sp. AM01 and Saccharicola sp. EJC04, respectively (Marques et al. 2018). Thus, suggesting potential endophytic strains capable of high cellulase enzyme system utilizing LCB as substrate. Similarly, various thermophilic and mesophilic bacterial strains were studied for the production of cellulase and belonged to genera Cellulosimicrobium, Clostridium, Thermomonospora, Cellulomonas, Ruminococcus, Erwinia, Bacteriodes, Bacillus, Streptomyces, Microbispora, Fibrobacter, Acetovibrio, Paenibacillus, and Aspergillus (Ahmad and Khare 2018; Cai et al. 2019; Mohapatra et al. 2018; Oliveira et al. 2018b; Prajapati et al. 2018; Liang and Xue 2017; Sriariyanun et al. 2016). Commercial fungal strains of Trichoderma are a well-known and commonly preferred fungal species for the production of cellulase utilizing cheap and readily available renewable substrates such as spruce, bagasse, wastepaper, dairy manure, and willow (Lan et al. 2013; Wang et al. 2020a).

Additionally, some food processing industries waste rich in lignocellulosic content such as brewery spent grain (BSG) and sugarcane bagasse (SCB) can be used for the production of cellulases using different fungal strains, i.e., Aspergillus niger CECT 2700, A. niger CECT 2915, and A. niger ITV-01 (Moran-Aguilar et al. 2021). The BSG and SBC are first subjected to alkaline/boiling water/autoclave pretreatments then subjected to SsF with selected Aspergillus niger strains. The maximum cellulase activity of $6.23 \mathrm{U} / \mathrm{g}$ using $A$. niger CECT 2700 and BSG pretreated with boiling water was reported (Moran-Aguilar et al. 2021).

Table 1 represents a summarized list of microorganisms used for cellulase production utilizing various LCB as substrate. 


\section{Cellulase production development strategies at laboratory and industrial scale}

Numerous strategies have been employed to increase cost-effective and economically feasible of the cellulolytic enzyme production using sustainable approaches. These include exploring different suitable carbon sources and pretreatment of agro-residues before using them for enzyme production. The media optimization and the role of different media components can be examined. In addition, the assessments of different process parameters have to be examined to increase cellulase production (Verma and Kumar 2020). Further advancement in cellulase production via microbial fermentation processes is also required. Further, microbial co-productions of other essential molecules is required for enhancing the cost efficiency of the overall process. Also, to increase cellulase efficiency via reusability concept and exploitation of different molecular approaches have to be examined for enhancing cellulase activity and efficacy. Some of the strategies have been discussed below.

\section{Utilization of suitable carbon source and pretreatment necessity of LCB}

The utilization of carbon sources can cause more than $50 \%$ of the total cost of enzyme production, e.g., pure glucose (Ellilä et al. 2017). The increasing demand for cellulase in various industries has led researchers to find multiple resources that can reduce production costs and be sustainable. As discussed earlier, microbial strains can be used to produce cellulase enzymes utilizing LCB obtained from forestry and agricultural residues as cost-effective raw materials that are abundantly available in nature (Kumar et al. 2008). Lignocellulosic plant residues can be an effective alternative to the costly carbon sources as they are cheap, renewable, abundant, and good nutrients sources for the microorganisms involved in cellulase production (Saini et al. 2017). Many lignocellulosic residues, such as wheat bran, sugarcane bagasse, rice straw, wheat straw, grape stalk, seeds, fruit pomace, corn cob, and soy bran, have been evaluated in the production of cellulases (Jampala et al. 2017; Masutti et al. 2015). Further, variation in atmospheric conditions results in different plant diversity and compositional structure, thus causing variations in the available waste. In Brazil, sugarcane bagasse is an effective alternative to the expensive carbon sources due to its large availability at the sugarcane mills (Vasconcellos et al. 2015).

Additionally, the substrates used in the production process acts as an enzyme inducer, and their source microorganism may produce enzymatic cocktails with diverse catalytic abilities for cellulose breakdown ( $\mathrm{Li}$ et al. 2017a; Pandey et al. 2016). Similarly, lignocellulosic substrates can be used as a suitable alternative to commercial inducers by producing a number of enzymes leading to better cellulose hydrolysis (Cunha et al. 2012). The use of waste biomass for cellulase production could reduce the production cost and partly address the environmental LCB disposal problems (Gomes et al. 2015).

Although celluloses are available in considerable quantities in the LCB, their accessibility to microbes is poor due to their natural recalcitrance properties in biomass. Thus, before using LCB as the substrate for cellulase production, it can be subjected to pretreatment to improve cellulose accessibility to microorganisms (Saini et al. 2017). After optimization and a suitable fermentation process, pretreatment of biomass can enhance the production of enzymes. The pretreatment of biomass is an effective method to disrupt the LCB complex structure, which increases the cellulose accessibility for fungal attack (Rodríguez-Zúñiga et al. 2014). Even though different pretreatment methods are known, such as biological, physical, chemical, and physicochemical pretreatment and their use mainly depends on the physio-chemical characteristics of the raw materials. Although various pretreatment methods are available, the two methods, i.e., chemical and thermochemical pretreatment, are currently in demand for most industrial applications (Alvira et al. 2010).

The major limitation associated with pretreatment methods is the generation of inhibitors, such as furfural and 5-hydroxymethylfurfural, etc. (Scordia et al. 2013). Thus, the type of pretreatment method strongly affects the proper growth of fungi as the presence of fermentation inhibitors compounds can inhibit fungal growth. Several types of research have been focused on minimizing these inhibition problems (Almeida et al. 2007). Vasconcellos et al. (2015) reported an improved enzyme production by removing the phenolic compounds, which are the known potential inhibitors of cellulase production. Sonication-based treatment of fermentation broth is suggested to have improved cellulase, xylanase, and pectinase enzymes production using different microorganisms (Delgado-Povedano and De Castro 2015; Jalal and Leong 2018). Increased glucose production from Bacillus licheniformis $\alpha$-amylase has been reported using ultrasound treatment at $100 \%$ amplitude for $1 \mathrm{~min}$ the ultrasound treatment to the sorghum grain slurry (Shewale and Pandit 2009). The amylase enzyme obtained by following this method has enhanced amyloglucosidase enzyme saccharification (by $8 \%$ ). 


\section{Media optimization and process parameters using statistical tools for enhanced cellulase production}

The various optimization studies have been performed to increase cellulase production using one factor at a time (OFAT) and different statistical approaches (Bhardwaj et al. 2017). The study shows that optimizing the medium components and the physicochemical process involved in the cellulase production process improved enzyme yield (Shajahan et al. 2017). A well-known statistical tool, Response Surface Methodology (RSM), was studied to optimize the cellulase production process to evaluate the interactions of independent physicochemical parameters in A. aneurinilyticus strain BKT-9 and Schizophyllum commune COC, (Kumar et al. 2018; Srinubabu et al. 2007). RSM is a multivariate approach with many benefits, such as a smaller number of investigational runs, increased justification of the statistical potentials, and individual and interactive properties of the involved parameters. The Central Composite Design (CCD) is a known statistical design under RSM with a rotatable feature while facing difficulty in star points extension beyond the upper and lower limits designed for each factor in the experimental region. The nutritional and environmental factors of cellulase production were optimized for bacteria obtained from Dal Lake, urban freshwater Himalayan Lake (Srinubabu et al. 2007). Shah et al. (2021) reported a new cellulase-producing strain Bacillus licheniformis KY962963, an epiphytic bacteria of marine algae Chlorococcum sp. The optimization of nutritional and ecological factors for enhanced cellulase production using Bacillus licheniformis KY962963 was performed using the concurrent application of "Plackett-Burman" design and one factor at a time approach. The study suggested that moisture content $(75 \%), \mathrm{K}_{2} \mathrm{HPO}_{4}$ concentration $(2 \mathrm{~g} / \mathrm{L})$ and incubation temperature $\left(35^{\circ} \mathrm{C}\right)$, and an incubation time of 3 days were optimum condition for enhanced cellulase production.

\section{Improvements in cellulase production via microbial fermentation processes}

The SsF and solid submerged fermentation (SmF) are the two main methods utilized for the production of cellulase and other enzymes like proteases, xylanase, and pectinases using different microorganisms (Mrudula and Murugammal 2011; Pant et al. 2015). Lignocellulosic feedstocks can be utilized as substrates that act as an inducer for enzyme production during fermentation. SmF possesses several advantages in process control as abundant water reduces the oxygen, temperature, and nutrient concentration gradients, and enzyme recovery is easy in SmF. Additionally, the submerged fermentation process can serve as a well-established technology to develop the fermentation processes for industrial-level production capability (Colla et al. 2016; Hansen et al. 2015).

Similarly, during SsF, an organic substrate is degraded aerobically in the absence of free water to produce the desired end-product. The optimal parameters vary extensively based on the fermentation process. Also, endproduct varieties can be generated by using the same substrate in varying operational conditions or by incubating with different microbial strains (de Castro and Sato 2015). Several reports suggest that SsF is an economical method for producing different industrially important enzymes and several other biochemicals by using lignocellulosic feedstock as substrate (Uncu and Cekmecelioglu 2011). There are several reports for cost-efficient cellulase production using SsF with LCB as substrate (Dhillon et al. 2012). It required simple equipment with lower energy needs resulting in high enzyme yield and significantly less processing costs. SsF and SmF using LCB as substrates is an added advantage to the process based on economic concern and promoting the search for effective substrates. Therefore, different strategies have been employed to reduce an enzyme's production cost, such as SsF using lignocellulosic plant residues as carbon source and enzyme inducer.

\section{Microbial co-production of other essential enzymes for the overall economy of the processes}

Along with cellulase, various other enzymes such as pectinase and xylanase have several applications in different fields such as waste treatment, value-added chemical production, field biofuel generation, etc. (Ali et al. 2013). Therefore, instead of using a single microorganism, researchers focus on those microbial cultures that can produce multiple enzymes (Li et al. 2018b). The biological processes have been used as an effective method for producing these essential enzymes from abundantly available substrates, and the cheap fermentation process is always in high demand (Ravindran and Jaiswal 2016; Singh et al. 2016). Among the applications of pectinase, cellulase, and xylanase co-production help in one critical application: finishing and degumming natural fibers, e.g., ramie fiber. Ramie fiber is composed of hemicellulose and pectin, which requires degumming to fulfill the textile industry's textile requirements (Zheng et al. 2001). The microbial co-production of essential enzymes (hemicellulase and pectinase) can be advantageous for this specific degumming process.

LCB is rich in lignin, cellulose, and xylan constituents and also several decomposer fungal strains are capable of producing these enzymes simultaneously for their natural growth. Thus, concurrent production of lignocellulolytic enzymes is a suggested method to decrease the 
overall cost of lignocellulolytic biorefinery. Jampala et al. (2017) suggested concomitant production of cellulase and xylanase from Trichoderma reesei NCIM 1186 and its enhancement via using desirability-based multi-objective optimization method.

Ultrasound-assisted treatment of fermentation broth has a positive effect on the co-production of fibrinolytic, cellulolytic, hemicellulolytic, and pectinolytic enzymes using different microorganisms (Avhad and Rathod 2015; Delgado-Povedano and De Castro 2015; Jalal and Leong 2018). Avhad and Rathod (2015) demonstrated that involving ultrasonication to induce enzyme production from microorganisms increased fibrinolytic enzyme yield. The process involved $12 \mathrm{~h}$ of bacterial growth from Bacillus sphaericus MTCC 3672 with optimized ultrasound treatment parameters of $25 \mathrm{kHz}$ ultrasound irradiation frequency with $40 \%$ duty cycle and $160 \mathrm{~W}$ power, which enhanced 1.48-fold cellulase production in a 1-L bioreactor (Avhad and Rathod 2015). Similarly, Yadav et al. (2020) demonstrated the effect of the ultrasonic treatment in enhancing the fermentative co-production of cellulase, xylanase, and pectinase enzymes from Bacillus subtilis ABDR01. Sonication of fermentation broth at ultrasound power of $90 \mathrm{~W}$ using $25 \mathrm{kHz}$ frequency with $70 \%$ duty cycle for 5 min gave the maximum cellulase, xylanase, and pectinase production of $22.17 \mathrm{U} / \mathrm{mL}$, and $137.95 \mathrm{U} / \mathrm{mL}$, and $87.82 \mathrm{U} / \mathrm{mL}$, respectively, at the short bacterial growth phase of only $6 \mathrm{~h}$. This study also suggested that the application of ultrasonic irradiation of fermentation broth causes cell cluster disaggregation and enhances the nutrient uptake along with maintaining the cellular integrity of microorganisms. This process caused a remarkable increase in the biomass concentration and end-product of the fermentation process.

\section{Strategies to increase cellulase efficiency and reusability}

Various strategies have been employed to increase cellulase efficiency and reusability. Some of these strategies have been discussed using different molecular approaches, as mentioned below.

\section{Molecular approaches via recombinant DNA technology to increase cellulase activity and efficacy}

The continuous increase in the requirement of resources for renewable energy has gained attention, and lignocellulosic plant biomass can be considered the most abundantly available carbon source in nature. The enzymatic hydrolysis process of cellulose components served as an effective process for the bioconversion of LCB to bioethanol due to its effective and economic properties (Sukumaran et al. 2009). Although the high production cost of cellulase contributes to half of the total cost of saccharification, it remains one of the major hurdles in the use of lignocellulose as a bioethanol source (Ariffin et al. 2008). Hence, for further reduction in the cost of cellulose-based ethanol production, microbial strains improvement can serve as a potential method for cellulase overproduction. A filamentous fungus Trichoderma reesei (Teleomorph Hypocrea jecorina) is the most widely studied organism for the complete set of cellulolytic enzymes production. Subsequently, its cellulolytic potential was documented in the late 1960s, and several studies have been performed for developing the mutants capable of producing efficient cellulases using conventional mutagenesis with physical and/or chemical mutagens (Chand et al. 2005; Zhang et al. 2006). Many high cellulase-producing T. reesei mutants have been reported, which are currently being used on a commercial scale. Their genetic basis responsible for enhanced production of cellulases is not known properly (Fujii et al. 2010; Zhang et al. 2006). A widely used mutant strain RUT C30 was observed lacking a genomic fragment of $85 \mathrm{~kb}$ and missing $~ 30$ genes that are involved in various biological processes while using genome walking in combination with complex oligonucleotides for determining the loci deletion (Seidl et al. 2008). The cloning of mutated genes using physical and chemical mutagens is a tedious process, hence, a reason for slow progress in mutations characterization at the molecular level (Gehring et al. 2000). Hence, using practical insertional mutagenesis approaches for discovering gene function in terms of cellulase formation can improve the strain properties and help understand the mechanisms responsible for the high cellulase production. The insertional mutagenesis has advantages, such as the mutated genes are tagged with inserted elements that can be used to identify the flanking sequences and the disrupted genes (Jeong et al. 2002). A flow diagram of strategies employed for increasing the cellulase efficiency and their characteristics are represented in Fig. 3.

\section{Application of bacteria-mediated transformation}

One of the most effective insertional mutagenesis approaches in fungi is Agrobacterium-mediated transformation (AMT) because of its high efficiency and mainly leads to single-copy T-DNA integration into the genomes (Michielse et al. 2005; Zhong et al. 2011). A PCR-based method, e.g., TAIL-PCR, can be used to amplify the genomic flanking sequences of T-DNA insertions and can be considered a strong tool for consequent reverse genetic mutants analysis (Combier et al. 2003). Several experiments performed using filamentous fungi in past years have positioned T-DNA as the favored insertion mutagen for the generation of 


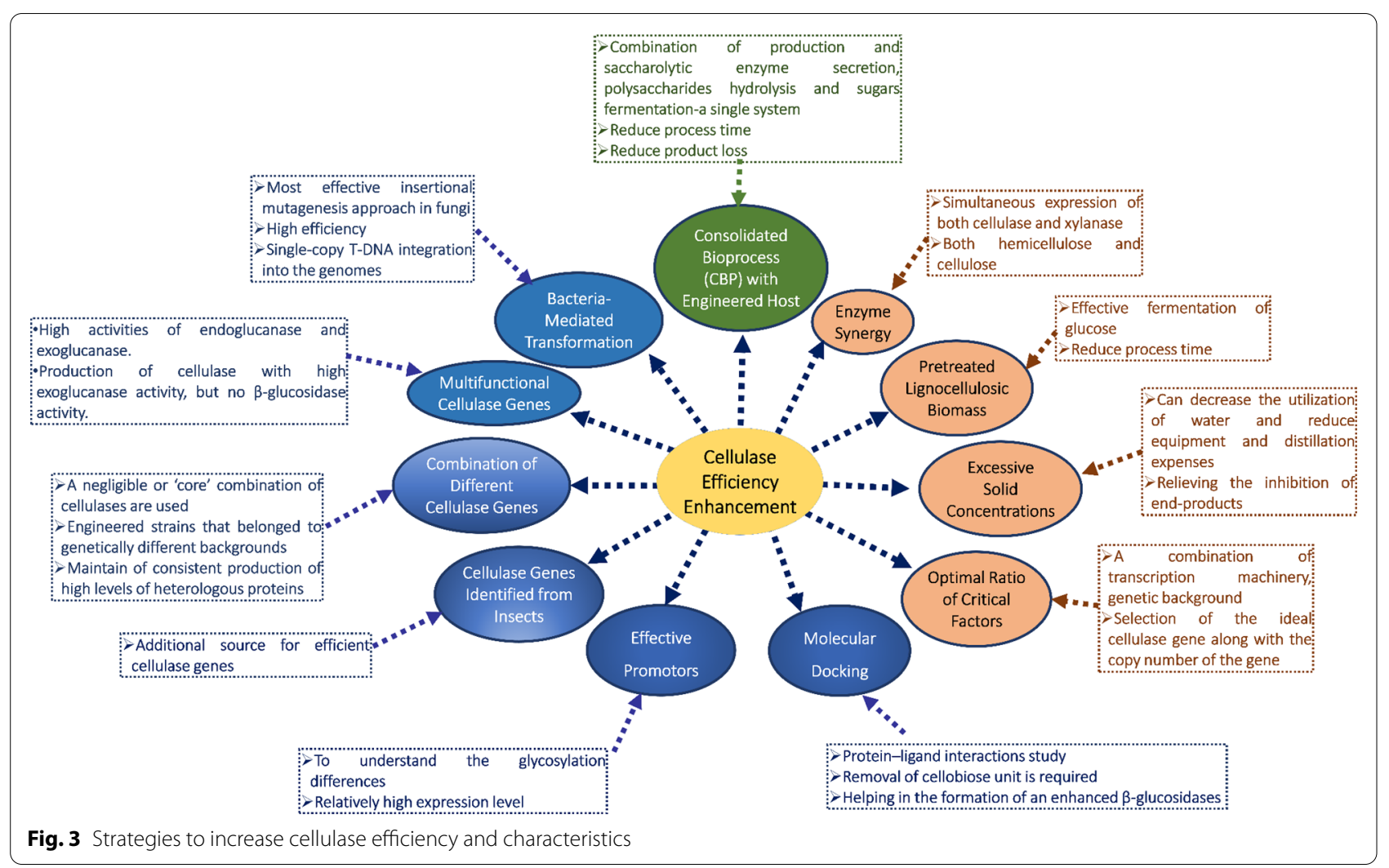

large-scale mutant libraries to identify the mutants of interest and interpret gene functions (Jeon et al. 2007).

Previously, an efficient Agrobacterium-mediated transformation (AMT) technique for random insertional mutagenesis has been reported in $T$. reesei, and the T-DNA inserts flanking genomic DNA sequences were released by the use of TAIL-PCR (Zhong et al. 2007). A T-DNA-tagged mutant library formation using AMT was reported for cellulase production improvement in which three putative mutants, i.e., TA-32, TB-87, and TE-6, with increased endoglucanase, cellobiohydrolase, and $\beta$-glucosidase activities with improved hydrolysis efficiencies were obtained by using 96-well plate screening on cellulose substrates for rapid growth and plate-clearing zone assay that resulted in $38 \%, 51 \%$, and $31 \%$ increased cellulase activity, respectively, as compared to parental strain QM9414. Additionally, T-DNA was integrated at a single site in the TA-32 genomes, and TE- 6 was inserted at two copies into the TB-87 genome. The sequences flanking the T-DNA insertion sites were rescued that explained its huge importance in cellulase production improvement and identification of tagged genes with cellulolytic activity (Zhong et al. 2012).

\section{Application of multi-functional cellulase genes}

Coprinopsis cinerea, a modulation in the multi-functional cellulase $(\mathrm{mfc})$ gene expression, was reported using glyceraldehyde-3-phosphate dehydrogenase (gpd) promoter fragments from Flammulina velutipes, Agaricus bisporus, and Lentinula edodes. In the culture liquid Cabm44 that used $A$. bisporus 275 bp gpd fragment, a submerged fermentation was performed using banana peels as a substrate for growth has reported the total cellulase activity of $0.26 \mathrm{U} / \mathrm{mL}$, highest activities of endo- $\beta$-1,4-glucanase, i.e., $0.48 \mathrm{U} / \mathrm{mL}$, and endo $\beta-1,4$-xylanase of $38.10 \mathrm{U} /$ $\mathrm{mL}$. This study reported the twofold increased lignocellulolytic enzymatic activities over wild-type strain (Yang et al. 2011).

An enhanced exo- and endoglucanase activities from $A$. niger cellulase have been reported to increase the cellulose hydrolysis efficiency and an appropriate enzyme composition. The exoglucanase or endoglucanase protein expression strategy was found helpful for P. rhizinflata cellulase (AF094747) as it showed high activities of endoglucanase and exoglucanase. P. rhizinflata cellulase depolymerization function was found better than that of T. reesei exoglucanase (Liu et al. 2001; Tsai et al. 2003), that is mainly used for the production of cellulase with high exo-glucanase activity, but no $\beta$-glucosidase activity 
as it may hinder the cellulose into glucose conversion (Xue et al. 2017a).

\section{Combination of different cellulase genes}

To get substantial hydrolysis of cellulosic substrates, at least a negligible or 'core' combination of cellulases is required to be produced. Some genes combinations, e.g., Trichoderma reesei endoglucanase (Tr-EGII), Talaromyces emersonii cellobiohydrolase (Te-CBHI), and Saccharomycopsis fibuligera $\beta$-glucosidase (Sf-BGLI) were expressed in yeast that resulted in partial hydrolysis of lignocellulose (Lambertz et al. 2014; Olson et al. 2012). Additionally, some engineered strains that belonged to genetically different backgrounds have shown the capabilities of a range of cellulolytic enzymes secretion (Dadwal et al. 2020; Davison et al. 2016, 2019a). Based on previous studies, it was observed that extremely high cellulase (20 FPU/g biomass) and $\beta$-glucosidase $(20 \mathrm{U} / \mathrm{g}$ biomass) loadings could decrease the concentrations of glucose significantly (Banerjee et al. 2010), that suggested that a satisfactory balance of cellulase activity is essential.

The stability of the increased expression cassette and copy number are the two important key steps involved in maintaining consistent production of high levels of heterologous proteins in S. cerevisiae in the biotechnological industry (Den Haan et al. 2013). It is necessary to understand the copy number effect on protein production ratios and its influence on hydrolysis and fermentation with the development of methods that supports stable, high copy numbers in yeasts, e.g., POT1-mediated delta

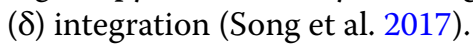

\section{Application of cellulase genes identified from insects}

Several organisms can utilize cellulose-rich biomass as a food source, such as insects. It involves the presence of cellulases, i.e., endoglucanases, exoglycanases, and $\beta$-glucosidases acting synergistically on LCB in their gut and digestive tract. In an approach to find new and efficient organisms that can be potential sources for cellulases, understanding the presence of cellulase in the gut and digestive tract of insects becomes a critical aspect. (Kim et al. 2008). Initially, the endogenous cellulase gene was discovered in termites. In insects, the endogenous cellulase genes have been isolated to date from termites (Nakashima et al. 2002), cockroaches (Lo et al. 2000), and beetles (Sugimura et al. 2003). Endogenous cellulases from insects have been reported in three glycosyl hydrolase families (GHFs): GHF 9 (termites and cockroaches), GHF 45 (beetles), and GHF 5 (beetles) that are phylogenetically and structurally unrelated. Among these, GHF 9 has been studied widely in termites. Based on previous studies, it can be observed that endosymbiotic and termite-derived cellulases are both present in termites (Nakashima et al. 2002; Scharf et al. 2003). An endogenous GHF 9 cellulase expressed in a wood-feeding termite Coptotermes formosanus is mainly found in the midgut, and the salivary glands have two independents cellulose-digesting systems. In first digestion of cellulose was carried out by endogenous cellulases that are in the midgut and second in the hindgut, where cellulases from the symbiotic flagellates were utilized (Nakashima et al. 2002). Another report on one endogenous GHF 9 cellulase from termite Reticulitermes flavipes, completely expressed in the foregut and the salivary gland, in which three symbiotic cellulases were exceedingly expressed in the hindgut, describing that endogenous and symbiotic cellulases acts in collaboration and serially throughout the whole digestive tract of $R$. flavipes (Zhou et al. 2007). Therefore, it can be concluded that EGs of GHF 9 is limited to the salivary glands, midgut, and foregut of termites, while EGs of GHF 7, GHF 5 and GHF 45 are restricted to the hindgut in which several cellulolytic flagellates are hidden (Ohtoko et al. 2000; Tokuda et al. 2007). In a previous work (Tokuda et al. 2007), researchers reported that termites cellulolytic systems support a dual cellulose-digesting system (Nakashima et al. 2002) instead of a single unified cellulose digestion system (Zhou et al. 2007). A novel endogenous $\beta$-1,4-endoglucanase (EG) gene that belonged to the glycosyl hydrolase family 9 (GHF 9) was distributed in the digestive tract of cricket (Teleogryllus emma), and it was cloned and characterized. TeEG-I gene consisted of eight exons encoding 453 amino acid residues and existed as a single copy in the T. emma genome. TeEG-I holds all properties of GHF 9 members involving catalytic domains and signature motifs that was highly identical with Mastotermes darwiniensis (termite) with $64 \%$ identical protein sequence, and Panesthia cribrata (cockroach) with $62 \%$ identical sequence from GHF 9 cellulases. At pH 5.0 and temperature $40{ }^{\circ} \mathrm{C}$ from a recombinant TeEG-I, expressed as a $47-\mathrm{kDa}$ polypeptide in baculovirus-infected insect $\mathrm{Sf} 9$ cells was reported, with $5.4 \mathrm{mg} / \mathrm{mL}$ and $3118.4 \mathrm{U} / \mathrm{mg}$ of $K_{\mathrm{m}}$ and $V_{\max }$ values, respectively, for the CMC digestion. The presence of TeEG-I was observed throughout the digestive tract in Northern and Western blot analysis. This suggested the correlation in the distribution of TeEG-I and cellulase activity in the digestive tract that was observed by immunofluorescence staining and enzyme activity assay, respectively. It also suggested TeEG-I distribution in the entire digestive tract of T. emma, which represents functional role of endogenous TeEG-I in the process of cellulose digestion (Kim et al. 2008).

Studies also showed recombinant cellulases from insects and performed significantly better than other 
cellulases (Hirayama et al. 2010; Kim et al. 2008; Willis et al. 2017). Hirayama et al (2010) reported successful cloning of two termite endogenous $\beta-1,4$ endoglucanases gene, i.e., RsEG (salivary gland of Reticulitermes speratus) and NtEG (midgut of Nasutitermes takasagoensis) gene using Aspergillus oryzae as host. The study clearly indicated that these two recombinant endoglucanases are highly efficient than those obtained previously from fungal or bacterial system. Recently, Wilis et al. (2017) performed successful expression of cellulase gene (TcEG1) gene from Tribolium castaneum in transgenic switchgrass. This cellulase was active at alkaline $\mathrm{pH}$ and helped in auto-hydrolysis of biomass with increased cellobiose release. Thus, this infused ability in biofuel crops to produce its own cell wall-digesting cellulase enzymes would help reduce the costs of cellulosic biofuel production.

\section{Current promotor utilization}

A multi-functional enzyme called EGX, directly isolated from $A$. crossean (an animal) with exo-b-1,4-glucanase, endo-b-1,4-glucanase, and endo-b-1,4-xylanase activities, was reported as the first multi-functional cellulase. Although the enzyme yield was produced from $A$. crossean it was not found optimal for the industrial level application (Wang et al. 2003). Therefore, EGX gene was overexpressed in Pichia pastoris and Saccharomyces cerevisiae (heterologous ascomycetous hosts) (Gao et al. 2007). Although this study showed that the heterologous expressions of the EGX gene in yeasts are not that suitable for biotechnological applications because of the glycosylation differences and relatively low expression level. Hence, a different strategy was used to overexpress the EGX gene in basidiomycetes that is the use of highly efficient promoters. Another report using this strategy using the controlled Lentinula edodes gpd promoter was with the antifreeze protein gene (afp) overexpression which was isolated from Choristoneura funiferana (an insect) in basidiomycete Volvariella volvacea (Wang et al. 2008).

Similarly, a green fluorescent protein gene (gfp) was overexpressed in basidiomycete Pleurotus nebrodensis (Lin et al. 2008). To date, no systematic evaluation of the efficiency of a promotor and heterologous expression of cellulase in basidiomycetes is available. Coprinus cinereus was found different from the other basidiomycetes. It is simple to be handled in DNA transformation with the transformation rates of up to 1000 transformants per microgram of DNA through the production of oidium (Granado et al. 1997). Recent studies on the use of molecular approaches in enhancing cellulolytic properties are listed in Table 2.

\section{Application of consolidated bioprocess (CBP) with engineered host}

Presently, commercial cellulosic plants for ethanol use individual hydrolysis and fermentation or SSF bioconversion techniques (Lynd et al. 2017). Although a Consolidated Bioprocess (CBP) configuration is defined as the combination of all production and secretion of the saccharolytic enzyme, polysaccharides hydrolysis, and available sugars fermentation within a single system is predicted to enhance process economics. The engineering of hosts like Saccharomyces cerevisiae is one of the favored methods for the development of CBP organism in which its ability to utilize cellulose was improved by expressing heterologous cellulase encoding genes (den Haan et al. 2015). The S. cerevisiae strain has been reported for effective fermentation of glucose obtained from pretreated LCB (Fujita et al. 2004; Yarbrough et al. 2015). Although no literature is found on the engineering of an S. cerevisiae strain, with the background of a natural strain isolate, having partial cellulolytic abilities which can help in the glucose fermentation obtained from pretreated biomass, which is a desired property for a $\mathrm{CBP}$ process. Some genetically different strains were transformed to produce core fungal cellulases, i.e., endoglucanase (EGII), $\beta$-glucosidase (BGLI), and cellobiohydrolase $(\mathrm{CBHI})$ in different combinations and expression configurations for the identification of a suitable genetic background for effective cellulolytic secretion. In the analysis of activity levels of the secreted enzyme, the copy number of a gene, substrate specificities, along with the transformants hydrolysis and fermentation yield and the bioconversion efficiency of the partially cellulolytic yeast transformants for the pretreated corn cob and corn husk. This study showed a higher secretion titer by cellulolytic strains with the YI13 genetic background, and 1.34-fold higher concentrations of glucose $(\mathrm{g} / \mathrm{L})$ were obtained with cellulolytic transformants compared to the control in which equal amounts of each enzyme type was present. The co-production of BGLI and EGII from the 1:15 secretion ratio (unit of cellulase activity per gram of dry cell weight) resulted in the conversion of $56.5 \%$ of the cellulose present in corn cob into glucose in hydrolysis procedure and yielded $4.05 \mathrm{~g} / \mathrm{L}$ ethanol. This study concluded that choosing an optimal genetic background and secretion ratio of cellulase activity can enhance the production of cellulosic ethanol by consolidated bioprocessing yeast strains (Davison et al. 2019b).

\section{Cutting-edge bioinformatics approach via molecular docking}

A computational tool known as molecular docking for protein-ligand interactions study and the structure prediction of the intermolecular complex formed between the molecules. It is a critical method that places ligand (a small molecule) in the binding sites of the receptor 


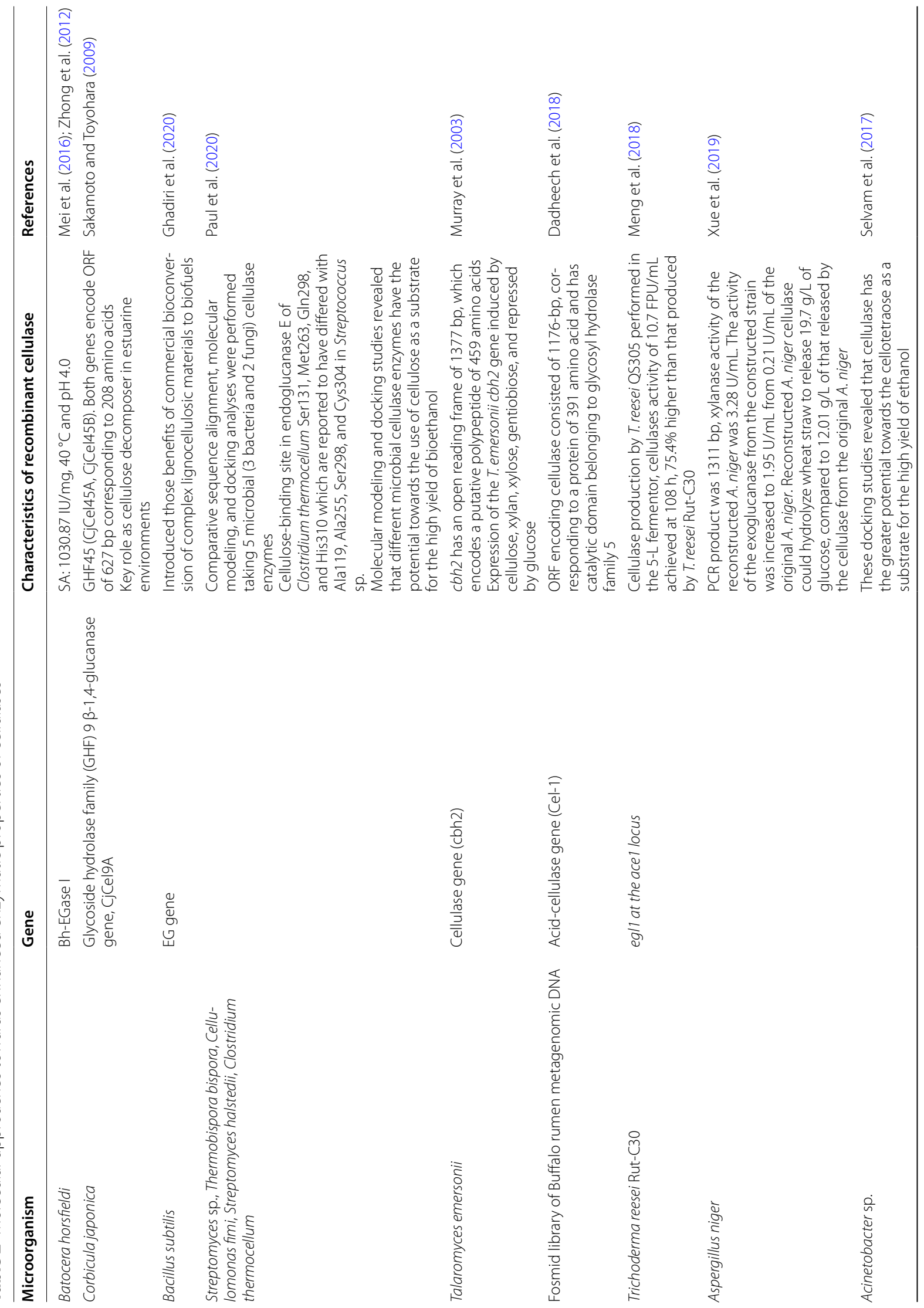




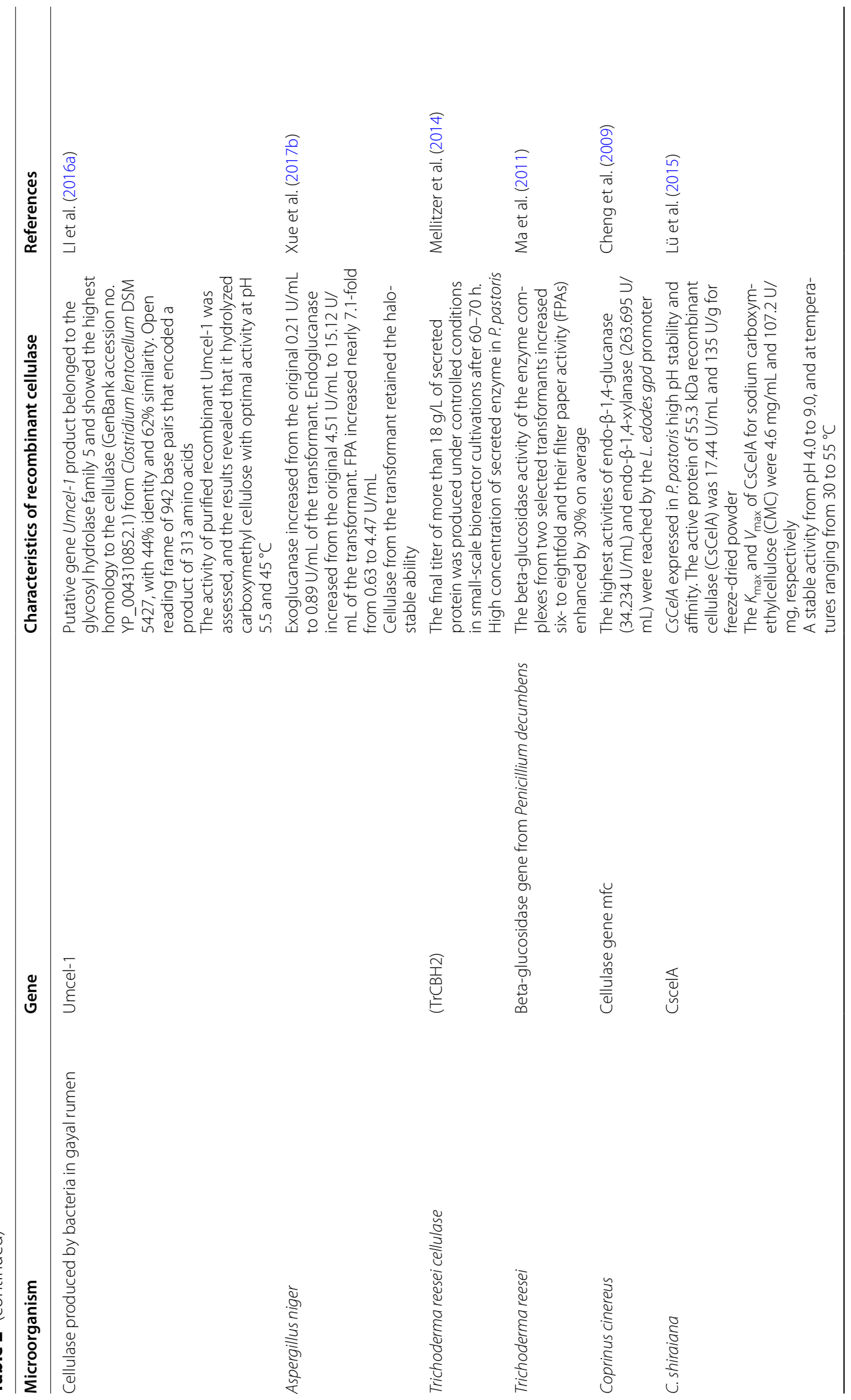




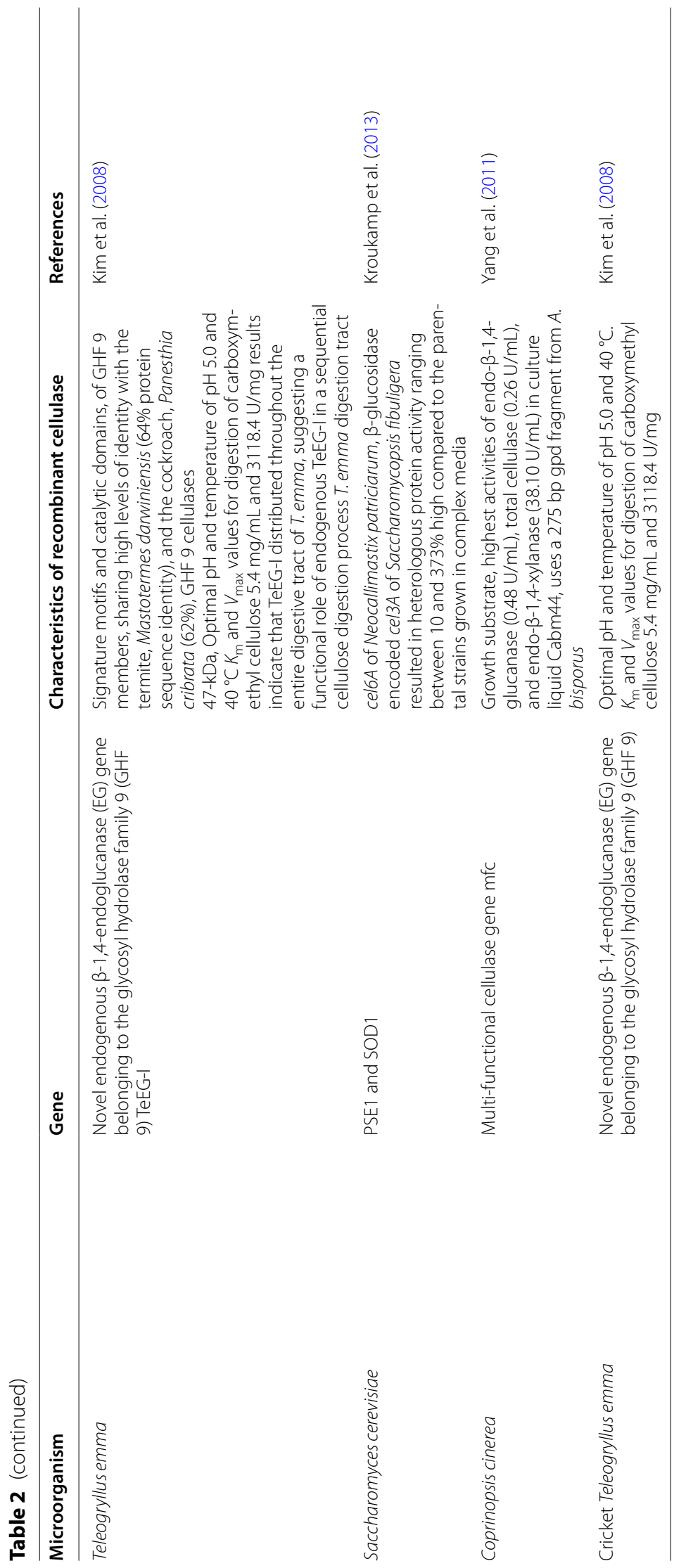


(macromolecular target) for determining the binding. In molecular docking, the binding mode is called the best match depending on the structures of proteins found between the ligand and lowest energy scoring pose determined by an energy scoring function (Ezat et al. 2014; Huang and Zou 2010; Sharma and Jha 2010).

$\beta$-Glucosidase completes the bioconversion process by the hydrolysis of residual cellobiose or cellotetraose into glucose. Cellobiose, an intermediate product, also strongly inhibits the endoglucanase and exoglucanase activity and is considered a key hurdle in enzymatic hydrolysis. Therefore, for the prevention of this inhibition process, the removal of the cellobiose unit is required and thus became a very crucial step in understanding the $\beta$-glucosidase catalytic activity for enzyme efficiency improvement, subsequently helping in the formation of an enhanced $\beta$-glucosidases. Less information is found related to the catalytic interactions between $\beta$-glucosidase and cellobiose. Considering this, an attempt was made to understand the Acinetobacter sp. cellulase binding efficiency that four polysaccharides subunits, cellobiose, cellotetraose, cellotetriose, and laminaribiose, while using the molecular docking method (Selvam et al. 2017).

\section{Innovative bioprocess development: synergistic enzymes applications}

Large quantity requirements of economic enzymes due to an increased number of biotechnological applications have subsequently increased the use of lignocellulosic feedstock as a potential energy source (Branco et al. 2010). Numerous techniques have been reported for the development of highly efficient cellulase (Ike et al. 2010), such as the use of UV-irradiated mutants (Ike et al. 2010) along with macro- and micro-mixing on enzymatic hydrolysis of lignocellulosic substrates into fermentable sugars (Chakraborty and Gaikwad 2010) and cellulase gene overexpression (Ribeiro et al. 2010), etc. Although lignocellulose degradation efficiency is not up to the mark due to the presence of both hemicellulose and cellulose, it is available as a carbohydrate source in plant material. As they are linked alternatively to each other, and action of individual xylanase and cellulase can only hydrolyze this holocellulose partially. Considering this, an approach for a simultaneous expression of both cellulase and xylanase is reported, in which a multi-functional cellulase gene from Ampullaria crossean stomach in Guangdong Province of South China (Cheng et al. 2009), showed that the exo- $\beta-1,4$-glucanase, endo- $\beta-1,4$-glucanase and endo- $\beta$ 1,4-xylanase activities ( $\mathrm{Li}$ et al. 2004; Wang et al. 2003). This gene can develop a novel engineering strain for the production of both cellulase and xylanase. During over expression of cellulase gene, over-glycosylation occurs causing low protein product expression level. The MFC, a multi-functional cellulase gene expressed in Coprinopsis cinereae, a basidiomycete large fungus that has the potential of exogenous genes overexpression (Cheng et al. 2009).

\section{Excessive solid concentrations utilization}

The end-product inhibition can act as a limiting factor during the enzymatic hydrolysis of cellulosic feedstockbased biorefinery. Thus, excessive solids concentration can decrease water utilization and reduce equipment and distillation expenses during hydrolysis of cellulosic feedstock. This strategy can provide an effective approach for generating high concentrations of end-products of hydrolysis, such as cellobiose and glucose. It has been observed previously that the inhibition rate of cellulases end-product is limited for the hydrolysis process of lignocelluloses in high-solid conditions (André et al. 2003; Kristensen et al. 2009). Therefore, it can be assumed that relieving the inhibition of end-products has become the main challenge with this approach and also in enzyme engineering (Andrić et al. 2010).

\section{A critical factor of optimal enzyme load during various industrial applications}

The cellulolytic organism's genomes encode a huge series of catalytic subunits that are evolved to overcome the challenges that occurred due to the heterogeneity of the chemicals and complexity in the structures of the naturally available lignocellulosic substrates. Moreover, some fine-tuning is performed through the expression regulation of the cellulases genes to the ratio of each of the cellulases for getting the maximum hydrolysis (Kunitake and Kobayashi 2017). Some of the most significant factors that majorly influence the conversion of the cellulosic substrate from recombinant strains are a combination of the transcription machinery, genetic background, selection of the ideal cellulase gene along with the copy number of the gene (Li et al. 2017b). The adjustment of optimal concentration and ratios of all the single cellulases in a heterologous system is a challenging step to attain the more effective hydrolysis process utilizing while using lower enzyme dosages (Li et al. 2017b). This can improve cellulolytic enzymes efficiency and serve as an active research area in which efforts are made to understand the synergy displayed by the cellulases combinations and ratio optimization (Den Haan et al. 2013). The target of this study was mainly the reduction in enzyme load for effective cellulose hydrolysis and eventually reducing the enzyme cost. Hence, it is clear that the difference in cellulase secretion abilities of $S$. cerevisiae can be clarified in terms of several factors along with genetic background impact (Davison et al. 2016, 
2019a; Marín-Navarro et al. 2011). Subsequently, internal and external pressures can affect the secreted recombinant protein yield in S. cerevisiae by using a background stress-tolerant strain, which can substantially affect the possibility and effectiveness of the bioethanol production using cellulosic materials (Gasser et al. 2008). The study of a total of thirty (30) natural isolates of S. cerevisiae was reported for the enhanced secretion activity along with other industrially important properties that are required for the lignocellulosic ethanol production process (Davison et al. 2016). A strain YI13 having a high secretory phenotype suggested 3.7 [Cel7A (CBHI)] and 3.5 [Cel5A (EGII)] fold higher secreted enzyme activity over control laboratory strain. Other industrially important properties were also observed in YI13, e.g., high titer of ethanol, growth vigor, high temperatures tolerance $\left(37^{\circ} \mathrm{C}\right.$ and $\left.40{ }^{\circ} \mathrm{C}\right)$, ethanol $(10 \% \mathrm{w} / \mathrm{v})$, along with several concentrations of an inhibitory compounds cocktail that are normally present in lignocellulose hydrolysate.

\section{Improvement in enzymes purification technique with enhanced specificity}

Purification is the second most crucial step in the fermentation process due to the involvement of a total $60 \%$ cost of the whole process. The downstream process (DSP) of cellulase production involves series of conventional purification methods, e.g., ion exchange and gel filtration chromatography followed by precipitation and membrane filtration individually or in combination with associated limitations (Sadhu et al. 2013b; Singh et al. 2015). Although several effective purification techniques have been reported at the laboratory scale, there are still some drawbacks associated with them. For example, the chromatographic technique is complex in large-scale applications as it require costly chemicals and loss of protein yield (Hofman and Thonart 2001). The risk of particulate plugging can degrade the purification efficiency of the enzyme in the case of membrane-based filtration. Similarly, ammonium sulphate low selectivity toward target proteins can be seen in the ammonium sulphate precipitation technique (Bajaj et al. 2009). An aqueous biphasic system (ABS) is an alternative to these conventional methods to overcome the drawbacks. It is a liquid-liquid extraction process that offers a suitable environment for various biomolecules recovery and a cost-effective method. It decreases the production cost by decreasing the number of steps in the downstream process. ABS has been identified as a fruitful method for biological materials recovery and is frequently utilized to extract and purify enzymes, cell organelles, proteins, and nucleic acids (Raja et al. 2011). Therefore, ABS can be served as an easy step for scaling up at industrial level production of biomolecules (Goja et al. 2013).

The use of a basic polymer polyethylene glycol (PEG) and sodium citrate salt ABS was reported to extract extracellular cellulase from B. subtilis. The physicochemical interaction between cellulase and phase forming chemicals determines the partitioning behavior of cellulases in the system depending on the differences in their hydrophobicity, volume extension, electrochemical charges, and surface properties (Mazzola et al. 2008). Recent purification techniques utilized for the purification of cellulases are listed in Table 3.

Table 3 Exploration of recent purification method for enhanced cellulase activity

\begin{tabular}{|c|c|c|c|c|c|c|}
\hline Strain and cellulase & Purification methods & S.A (IU) & Yield (\%) & Purification fold & Mol. Wt. (kDa) & References \\
\hline \multirow[t]{3}{*}{ Bacillus tequilensis G9 } & Ammonium sulfate precipitation (70\%) & $26,505 \pm 90$ & 21.7 & 3.6 & 43 & Dar et al. (2019) \\
\hline & Acetone precipitation & $44,602 \pm 50$ & 21 & 3.74 & & \\
\hline & $\begin{array}{l}\text { lon-exchange chromatography } \\
\text { technique (DEAE)-cellulose column } \\
(25 \times 2 \mathrm{~cm}) \text { equilibrated with } 20 \mathrm{mM} \\
\text { PBS (pH 7.4) }\end{array}$ & & & 9.89 & & \\
\hline \multirow[t]{3}{*}{ Pleurotus ostreatus } & Ammonium sulphate precipitation & 36.8 & 54 & 10.5 & 58 & Okereke et al. (2017) \\
\hline & Dialysis & 52.0 & 30.5 & 14.9 & & \\
\hline & Gel filtration Chromatography & 61.0 & 17.4 & 17.4 & & \\
\hline Bacillus subtilis & $\begin{array}{l}\text { Polyethylene-glycol (PEG)/sodium } \\
\text { citrate aqueous biphasic system (ABS) }\end{array}$ & - & 82.86 & 4.8 & $32-46$ & Ho et al. (2017) \\
\hline Bacillus sp. H1666 & $\begin{array}{l}\text { Acetone precipitation followed by ion } \\
\text { exchange and size exclusion chroma- } \\
\text { tography }\end{array}$ & & 29 & 66.23 & 40 & Harshvardhan et al. (2013) \\
\hline $\begin{array}{l}\text { Rhizopus stolonifer } \\
\text { var. reflexus TP-02 }\end{array}$ & $\begin{array}{l}\text { Ammonium sulphate followed by } \\
\text { dialysis, ultrafiltration, and Sephadex } \\
\text { G-100 }\end{array}$ & 121.31 & & 34.96 & $40-46$ & Tang et al. (2012) \\
\hline
\end{tabular}




\section{Reusability of cellulolytic enzymes: a recent advancement in cellulase immobilization}

Tremendous research has been carried out over the past decades to fulfill the high demand for cellulases in various industrial processes and strategies to enhance the production of cellulases. In addition, also novel microorganisms were employed. It was found that native cellulases had low stability and activity problems along with high cost. These problems could be reduced in two ways. First, the production of cellulase must be economically feasible or by immobilization, which can provide better stability and applicability of the enzyme for the industrial processes (Cao 2005). Immobilization can improve the activity and performance of specific cellulase by reducing the amount of enzyme required for the process (Cao 2006). For the hydrolysis of different cellulase immobilizing techniques have tried which involved chitosan covalent immobilization ( $\mathrm{Su}$ et al. 2012), on water-soluble copolymer (Liang and Cao 2012), in hybrid matrices by sol-gel encapsulation (Ungurean et al. 2013), on magneto responsive graphene nano-supports (Gokhale et al. 2013), etc. Most of the recent cellulase immobilization techniques and their outputs are listed in Table 4.

\section{Physical adsorption}

This process works on the concept of reversible immobilization in which physical adsorption or attachment of enzymes occurred onto the support material through weak non-specific forces such as hydrogen bonds, Van der Waals, and hydrophobic interactions (Kumar 2009). This process has high commercial potential as its processing cost is comparatively low and straightforward. But it has drawbacks like leakage of immobilized enzyme reduces the activity of enzymes after multiple cycles (Won et al. 2005). There are three modes from which enzymes and bio-carrier usually interact, i.e., hydrogen, electrical bonding, and hydrophobic (Nussinovitch 2010; Won et al. 2005). Biocarrier screening is an essential step towards the improvement of an effective bio-catalytic process for specific industrial applications. The selection of solid support can be done by three fundamental measures, i.e., physical/mechanical strength, cost-effectiveness, and chemical stability (Guisan 2006). Affinity binding is also one of the physical adsorption methods that involve selecting biomolecules to be applied in the immobilization of enzymes.

\section{Covalent bonding}

This process comprises a multipoint linkage between the support surface and enzyme, which causes strong attachment. Support reuse is not permitted in the process because there are possibilities of breakage in the enzyme support during the elution of enzymes. Also, the substantial reduction in the activity of enzyme after multipoint covalent attachment is possible because of the enzyme's movement restriction and conformational changes on they might be due to restriction of the movement of the enzyme, conformational changes on the carrier surface, or mass transfer effects (Singh et al. 2013). The effective enzyme separation was reported with $\mathrm{Fe}_{3} \mathrm{O}_{4}$ magnetic particles through magnetic field modulation. Although agglomeration occurred, affecting the mass transfer rate (Lima et al. 2017).

\section{Cross-linking immobilization}

An attempt was made on cellulase immobilization without a carrier as no solid carrier is required to obtained high enzyme activity per unit volume (Seow and Yang 2017). Cross-linked enzyme aggregates were reported to be an effective alternative to the traditional solid carriers immobilization methods due to high volumetric activity, stability, economic production, easy process, reusable, no use of no purity enzyme, and no solid carrier requirement (Sheldon 2011b; Yamaguchi et al. 2018). No mechanical resistance (improvable by dehydration hardening and intense cross-linking) (Garcia-Galan et al. 2011), enzyme mobility reduction, and limitations in the internal mass transfer are the drawbacks of cross-linked enzyme aggregates which can be problematic for macromolecular substrates (Cui and Jia 2015).

Native enzymes' less activity was believed due to carbamates inactivation on the enzyme surface with lysine residues and local $\mathrm{pH}$ reduction due to carbonic acid formation (Dijkstra et al. 2007). Improvement in the enzymatic activity by supercritical carbon dioxide was reported by various scientists (De Souza Melchiors et al. 2017; Melgosa et al. 2015). The cross linked enzyme aggregate (CLEA's) is a type of immobilization without application of any carrier. In CLEAs, cellulase is crosslinked with glutaraldehyde for obtaining active and stable enzyme preparation (Podrepšek et al. 2019). An immobilized cellulase on amino-functionalized MNPs $\left(\mathrm{Fe}_{3} \mathrm{O}_{4} @\right.$ $\mathrm{mSiO}_{2}-\mathrm{NH}_{2}$ ) using glutaraldehyde as a cross-linking agent by Schiff base formation showed efficient prevention in enzyme leaking and improvement in enzyme activity (Fang et al. 2016).

\section{The industrial perspective of cellulolytic enzymes}

Attention toward cellulase and other cellulolytic enzymes has considerably increased due to their importance in the hydrolysis of cellulosic materials to fermentable sugars to produce value-added products such as biofuel (Soares-Silva 2016; Kumar and Verma 2020b). Some 


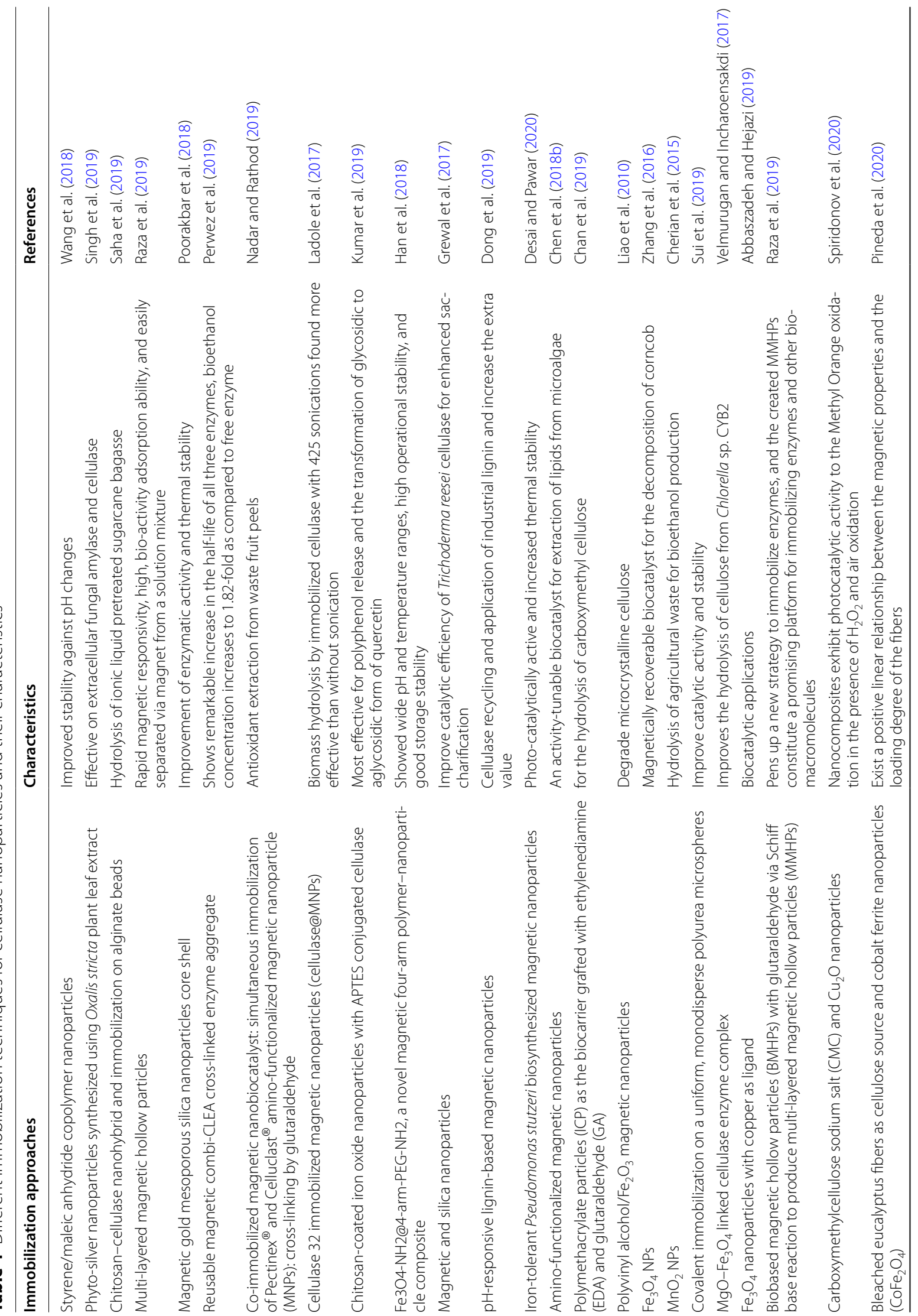




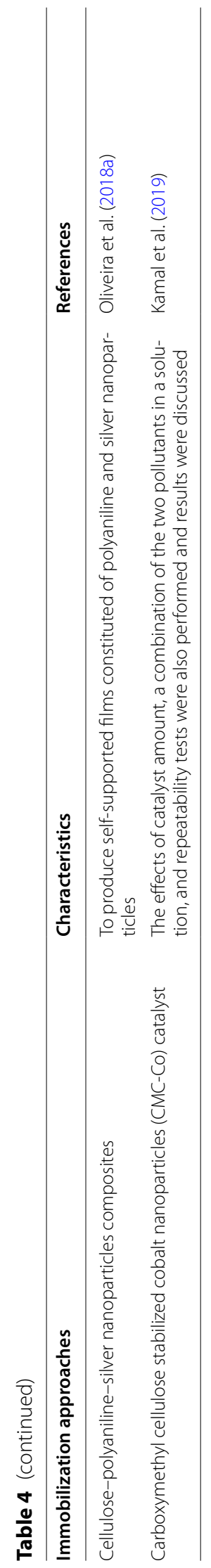


recent developments in the applications of cellulases are described below. Some recent developments in the applications of cellulases are described below.

\section{Paper and pulp industries}

Considering the limited availability of petroleum resources (Sepehri et al. 2020), cellulosic materials have attracted much more attention as they have renewable and biodegradable features (Shi et al. 2019; Thomas et al. 2018). Pulp dissolution with more than $90 \%$ of pure cellulose was found in the special commercial pulp with many downstream applications, e.g., micro filters, cellulose esters/ethers, viscose rayon, and lyocell (Arnoul-Jarriault et al. 2015; Li et al. 2016b). For all these applications, viscose rayon production utilized nearly three-quarters of the dissolving pulp production (global annual production was $\sim 8$ million tons) (Kumar and Christopher 2017). In the production of dissolving pulp mainly two commercial processes are involved, i.e., acid sulfite (AS) and pre-hydrolysis kraft (PHK). However, AS is preferred more because of the compatibility with different raw materials along with the alkali recovery units effectiveness (Li et al. 2016b). PHK has shown a low reactivity problem because accessible hydroxyl groups are not synthesized by the alkaline peeling reaction of PHK pulping. Hence, further upgrading technique is much needed to increase the reactivity of PHK pulp that can determine the consumption of toxic carbon disulfide in the xanthation stage of production of rayon. Various studies have been reported for further PHK pulp up-gradation, e.g., mechanical treatment (Tian et al. 2014), enzyme treatment (Li et al. 2018a), chemical treatment (Wang et al. 2014), microwave (Liu et al. 2018), ionic liquor, and electron beam irradiation (Chen et al. 2017). From all these tested methods, cellulase treatment was found as an effective approach with green and mild behavior. Cellulase treatment may increase the reactivity of fock in dissolving pulp from 47.7 to $79.9 \%$ with $2 \mu / g$ and $2 \mathrm{~h}$ cellulase dosage (Miao et al. 2014) and observed that cellulase treatment could increase fock reactivity of dissolving pulp. A new cellulase spraying method is also reported for upgrading the dissolving pulp with an increase in fock reactivity from 51.2 to $82.6 \%$ under $60 \%$ pulp consistency condition with $1.5 \mathrm{mg} / \mathrm{g}$ and $12 \mathrm{~h}$ cellulase dosage ( $\mathrm{Li}$ et al. 2018a).

Although the efficiency of cellulase was hindered due to the inherently compact nature of the cell wall structure and aggregation of fibrils, that was more complicated after multiple bleaching and pulping stages of the PHK production process. Large amounts of lignin and hemicellulose removals can create spaces and pores for new aggregation and generate structures with less accessibility (Engström et al. 2006). The cationic polyacrylamide
(CPAM) addition can induce the cellulase adsorption ratio by the bridging and patching effect, eventually increasing the efficiency of cellulolytic enzymes. Apart from the integrated mechanical treatment, cellulase treatment can serve as an alternative practical method for upgrading the dissolving pulp. Mechanical refining has been used in several areas (Mou et al. 2014), e.g., a commercial process of papermaking (Chen et al. 2012), production of nano-/micro-fibrillate fiber ( $\mathrm{He}$ et al. 2018), and digestibility of enzymes (Wang et al. 2012). The remarkable increase in breaking length, stretch, and tensile index (Chen et al. 2012) 41.6\%, 33.5\%, and 30.8\%, respectively, was observed from a beaten pulp of $54^{\circ} \mathrm{SR}$ as compared to an unbeaten pulp. Only a few studies have been reported to date describing the effect of depth refining on hydroxyl groups' liberation and accessibility of enzymes, mainly while the activation of dissolving pulp using cellulase. In terms of considering reactivity, a critical factor of dissolving pulp can determine the consumption of toxic chemicals such as carbon disulfide in rayon production. A detailed refining to improve the PHK pulp before the treatment of cellulase was studied for describing that the mechanical refining can not only enhance the reactivity by liberating additional hydroxyl groups, but also increases the efficiency of cellulases by improving the accessibility of enzymes. This study showed a clear increase in fock reactivity of refined pulp at beating degree of $50^{\circ} \mathrm{SR}$ from $54.8 \%$ of the original at beaten degree $19^{\circ} \mathrm{SR}$ to $78.0 \%$, mainly due to the changes in the intermolecular hydrogen bond.

Additionally, an increase in a range of $39.7-71.2 \%$, adsorption ratio of cellulase from the refined pulp (30$50^{\circ} \mathrm{SR}$ ) was reported to verify the enzymatic accessibility improvement. An integrated process involving mechanical refining and $0.5 \mathrm{mg} / \mathrm{g}$ of cellulase dosage treatment resulted in better efficiency than the control with $1 \mathrm{mg} / \mathrm{g}$ pulp of cellulase dosage considering the increase in reactivity and reduced viscosity. Other pulp properties, e.g., length of the fiber, the value of water retention, specific surface area, morphology, and crystallinity, showed the depth refining positive effect on dissolving pulp activation during treatment cellulase (Wang et al. 2020b).

The ideal concept for biorefinery is the complete utilization of LCB (Van Heiningen 2006). A well-known commercial practice for dissolving pulp is kraft-based Pre23 hydrolysis that supports this ideal concept as they separate hemicellulose, cellulose, and lignin in several streams (Miao et al. 2014). The dissolved pulp can be used for several applications, e.g., cellulose derivatives and viscose rayon production. The adjustment of reactivity and viscosity is one of the most critical challenges in dissolving pulp production. Cellulase treatment has been reported as an effective approach for reducing viscosity 
and increasing enzyme reactivity. The use of endoglucanase in the treatment of cellulase mainly degrades amorphous cellulose present on the surface of the fiber and in-between the microfibrils that enhance the exposure of crystalline surface, pulp reactivity, and swelling ability (Ibarra et al. 2010).

The recycling of cellulases can be an effective method for reducing the cost of enzymes. After the enzymatic treatment of dissolving pulp, cellulase as a catalyst remains in the liquor phase itself. Reuse and recovery of the liquor can reduce the enzyme cost and attain zerowater release in the stage of enzymatic treatment. Cellulase recycling has been studied previously in the year 1971 in the lignocellulose bioconversion process. The recyclability of various cellulases can be obtained considering the enzymatic substrate during the study of biofuel production. Economic point is an important concern during the enzymatic treatment of dissolving pulp for industrial-level application. The cellulase recycling strategy using fresh cellulase was reported to activate the dissolving pulp, i.e., enhancing fock reactivity and decreasing viscosity. According to the study, 48.8-35.1\% of cellulase activity can be recovered in five recycle rounds from the filtered liquor that can be utilized again for the dissolving pulp enzymatic treatment. The recycling of cellulase and additional fresh $1 \mathrm{mg} / \mathrm{g}$ led cellulase to the pulp with $470 \mathrm{~mL} / \mathrm{g}$ viscosity and $80 \%$ fock reactivity comparable with $2 \mathrm{mg} / \mathrm{g}$ cellulase charge (Wang et al. 2016).

\section{Food and feed applications Clarification of juice}

Cellulolytic enzymes are useful for food processing industries such as juice clarification. The disruption of the vegetable cell wall is caused during pressing and releasing the internal juice in the grape juice processing. The freshly pressed juice is cloudy and turbid due to the colloidal dispersion of pectin and is considered a significant hurdle in juice processing (Irshad et al. 2017; Tapre and Jain 2014). In addition to this, cellulose and hemicellulose-like polysaccharides get settled during the storage resulting in a flavorless and clear-colored water-like juice is a significant problem (Vaillant et al. 2001). The commercial enzyme preparations mainly using hemicellulases, cellulases and pectinases are widely used in fruit juice industries to overcome these problems. In their soluble forms, these enzyme preparations play a vital role in the hydrolysis of such compounds, improve filtration, juice clarification, and stabilization (Romero-Cascales et al. 2012; Sandri et al. 2011).

Immobilization methodology has appeared as an effective approach to develop heterogeneous biocatalysts and enhance enzyme recovery (Krajewska 2004). Enzyme immobilization has shown stability in difficult reaction conditions, simplifies the separation of the enzyme from the reaction systems, allows biocatalyst reusability during the continuous process and mainly during multiple reaction cycles, and increases their commercial, industrial importance (Garcia-Galan et al. 2011). Previous studies have suggested that the enzyme immobilization could be utilized for the apple, carrot, grape, pineapple, and orange juices clarification (Sojitra et al. 2017). Although there is no immobilization method was industrially applied for such purpose due to costly processes and economically less feasible. Thus, this opened a new area for new research. Generally, covalent immobilization has been preferred as it may prevent desorption of enzymes from the support during the reaction (GarciaGalan et al. 2011; Rodrigues et al. 2013; Royvaran et al. 2016). Additionally, support type is a critical factor in the enzyme immobilization process, as it may affect the enzyme loading amount and its operational stability and catalytic activity (Cao et al. 2003; Miletić et al. 2009; Pal and Khanum 2011).

Usually, small size biocatalysts are gaining more attraction due to their high specific surface area available for the attachment of enzymes. Although the separation step from the reaction medium may be difficult due to the sedimentation of insoluble components in juice clarification. Immobilized enzymes separation from the sediments is difficult by conventional processes, e.g., centrifugation and filtration. Thus, magnetic particles could be utilized as efficient support for the immobilization of enzymes to reduce these limitations because their magnetic core offers efficient, easy, and quick enzyme separation from the reaction mixture by utilizing the external magnetic field; additionally, its size can be personalized to offer high surface and increased enzyme activity (Ansari and Husain 2012; Laurent et al. 2008) since these magnetic particles are susceptible to oxidative and acidic conditions. Hence, their functionalization is very important for stability maintenance (Wu et al. 2008).

Carrier-free biocatalysts are found to be another approach for enzyme immobilization. Cross-linked enzyme aggregates (CLEAs), generally prepared by the direct cross-linking of different enzyme preparations (Sheldon 2011a), offer several advantages for increased and concentrated enzyme activity with high stability and economical production process because of the elimination of an additional carrier (Cao et al. 2003). Therefore, two different magnetic biocatalysts were prepared for the application in juice clarification targeting to help biocatalyst separation (Dal Magro et al. 2018). 


\section{Cellulase in animal feed improvement}

There are several other advantages associated with cellulase-producing bacteria, such as probiotic activity. (Kewcharoen and Srisapoome 2019) The probiotic bacteria are rich in cellulases and are vital to the utilization, digestion, and absorption of animal feed, mainly in young animals with imperfect digestive systems (Li et al. 2020). Also, cellulases from bacteria such as Bacillus subtilis are used for the nutritional enhancement of animal feed. These processed feeds are exploited to enhance body weight gain, milk yield, etc.

Further, animal feed processing with these enzymes can help remove anti-nutritional factors present in grains and other cellulosic materials (Jayasekara and Ratnayake 2019). Tahir et al. (2005) suggested that the processing of corn-soybean meal of broiler chicken via a combination of cellulase and hemicellulases has a synergistic effect on the performance of the feed. Lucio et al. (2021) presented a comprehensive review on the effect of enzymes as zootechnical additives in animal feed. The review provided evidence on the positive effect of cellulase addition in food supplement processing for animals.

\section{Cellulase applications in biorefinery industries}

Environmental pollution-related concerns and limitations in oil supply with continuous increase in global demand for energy have substantially induced the urgent requirement of cost-effective alternatives towards the renewable, clean, and maintainable production of biofuel (Hyeon et al. 2016). Hence, various products of biorefinery industries such as bio-butanol, biomethane, bioethanol, biohydrogen, and biodiesel have been introduced as an effective alternative to the petroleum-based resources to bio-based and eco-friendly energy resources (Abraham et al. 2014; Alexandri et al. 2019). Concerning the biorefinery industry, lignocellulosic plant biomass is the most effective, economic, renewable, and most abundant natural resource that has been widely studied without affecting or competing with the food industry (Zabed et al. 2016). The proper bioconversion process of lignocellulose obtained from the plant biomass require the involvement of enzymatic hydrolysis, where cellulolytic enzymes play a key role in breaking down the cellulosic polysaccharide structure into fermentable sugar molecules (Lynd et al. 2008; Obeng et al. 2017; Thapa et al. 2020). Enzymatic hydrolysis using cellulases offers a more efficient bioconversion system due to having more specificity towards substrates, better saccharification, less complexity, and environment friendly when compared to non-enzymatic hydrolysis system (Ungurean et al. 2013).

A study reported that effective polymer-enzyme bioconjugates with more stability and activity for practically using cellulases in LCB hydrolysis. A dual cross-linking (DC) approach was reported for the synthesis of a novel 3D network of CMC grafted copolymers of 2-acrylamido-2methyl propane sulfonate and acrylamide [CMC-g-poly (AMPS-co-AAm)] hydrogels. Graphene oxide (GO) nanosheets were used as nanofiller and physical cross-linker, which were forming $\mathrm{H}$-bonds between polymeric chains for the preparation of GO@CMC-g-poly (AMPS-co-AAm) networks. For examining the effect of GO content on the effectivity of synthesized architectures in conjugation to a control enzyme known as PersiCel1. Immobilization of PersiCel1 on the GO reinforced hydrogels which showed a remarkable retaining approx. $60 \%$ of its maximum activity at $90{ }^{\circ} \mathrm{C}$ and increased specific activity and storage stability. Compared to free control PersiCel1, the immobilized enzyme resulted in a $154.8 \%$ increase in alkaline treated sugar beet pulp bioconversion, whereas the PersiCel1/neat-Hydrogel showed $66.7 \%$ increment, under the same conditions (Ariaeenejad et al. 2020).

Gracilibacillus SK1, a halophile isolated from Yuncheng Salt Lake was reported for cellulolytic activity, in which production of cellulase was strongly affected by the culture medium salinity with the highest level in the presence of $10 \% \mathrm{NaCl}$. A multi-component enzyme system was observed during the substrate specificity test with a combined activity of $\beta$-glucosidase endoglucanase and exoglucanase, which is confirmed by zymogram analysis. The crude cellulase with high activity and stability over broad temperature range, i.e., $40-70{ }^{\circ} \mathrm{C}, \mathrm{pH}$ ranging from $6.0-10.0$ and $7.5-17.5 \% \mathrm{NaCl}$ concentration with the temperature and $\mathrm{pH}$ optima of $60{ }^{\circ} \mathrm{C}$ and 8.0, respectively, with $12.5 \% \mathrm{NaCl}$, resulted in thermo-alkali stable and halo-stable properties. Also, it showed high stability in the presence of hydrophobic organic solvents.

Corn stover and rice straw saccharification were reported using cellulase with 0.678 and $0.502 \mathrm{~g}$ yields of reducing sugars with $\mathrm{g} / \mathrm{L}$ of dry substrate, respectively, that was later utilized to produce ethanol using Saccharomyces cerevisiae. The crude cellulase from Gracilibacillus sp. SK1 reported the efficiency of bioethanol production with the yield of ethanol $0.186 \mathrm{~g} g / \mathrm{L}$ of the dry substrate and a $52.8 \%$ conversion percentage ( $\mathrm{Yu}$ and $\mathrm{Li}$ 2015). The extraction of natural components from plants using enzymes has been widely studied. They offer many advantages compared to traditional methods, e.g., simple operation, more efficient, and economic process. Many studies in the biomolecule extraction process are mainly reported using cellulase, pectinase, and glucosidase for the hydrolysis and degradation of cell wall components and subsequently releasing the intracellular ingredients. The conventional enzyme-based extraction is complex, tedious, and needs high-energy consumption, eventually limiting its large-scale application (Chen et al. 
2016). Anionic liquid-based enzyme extraction system of geniposide, coupled with in situ hydrolysis from Eucommia ulmoides Olive barks, is reported using enzymatic hydrolysis. A single cellulase was used to extract and hydrolyze geniposide in a continuous system (Chen et al. 2018a).

Aspergillus fumigatus $\mathrm{Z} 5$, with the lignocellulosic decomposing ability and has the capacity to produce cellulase, was reported under SsF using lignocellulosic feedstock as substrates. The optimization of cellulase production from A. fumigatus Z5 and resulted that carboxymethyl cellulase (CMCase) and filter paper enzyme (FPase) production at $50{ }^{\circ} \mathrm{C}, 80 \%$ initial moisture, initial $\mathrm{pH} 4.0$, and 7\% initial inoculum with CMCase and FPase activity, 526.3 and $144.6 \mathrm{U} / \mathrm{g}$ dry weight, respectively. $A$. fumigatus $\mathrm{Z} 5$ reported a total of eight types of cellulases under zymogram analysis in the presence of cellulosecontaining materials in the culture. The crude cellulase from A. fumigatus Z5 was found capable of hydrolyzing pretreated corn stover for bioethanol production by using Saccharomyces cerevisiae, with $0.112 \mathrm{~g}$ g/L dry substrate ethanol yield (Liu et al. 2011). The study aimed to produce a cellulase blend and evaluate its application in a SSF process for second-generation ethanol production from sugar cane bagasse.

The residual solid fraction obtained from a diluted acid and alkaline pretreated sugar cane bagasse was subjected to cellulase production and ethanol fermentation using a SSF process. A bioreactor with two inoculum concentrations ( 5 and $10 \% \mathrm{v} / \mathrm{v}$ ) was used for cellulase production by inoculating a larger inoculum size for high yield. Tangential ultrafiltration in the hollow fiber membrane was used to concentrate the cellulase extract, which was stable for $300 \mathrm{~h}$ at $37{ }^{\circ} \mathrm{C}$ and $50{ }^{\circ} \mathrm{C}$. This on-site cellulase blend was used to produce bioethanol by using the PDC fed-batch SSF process. The feeding method avoided the characteristic problems of limitations in diffusion by decreasing the high solid presence:liquid ratio at any time and resulted in a high ethanol concentration at the process end $(100 \mathrm{~g} / \mathrm{L})$ and showed a $78 \%$ fermentation efficiency resulting from the ratio of $380 \mathrm{~L}$ of ethanol per ton of sugar cane bagasse PDC (Maeda et al. 2013).

A filamentous fungi Penicillium oxalicum for cellulase production in submerged fermentation in shaking condition was reported with a cellulase activity of $0.7 \mathrm{FPU} / \mathrm{mL}$. After the process optimization, cellulase production was increased by 1.7 -fold resulted in a maximum cellulase activity of $1.2 \mathrm{FPU} / \mathrm{mL}$ in 8 days of incubation. A successful scaled-up system of 7-L fermenter was studied for cellulase production under controlled conditions, which showed a decrease in incubation time from 8 to 4 days for attaining a similar cellulase yield. $\mathrm{pH}$ and temperature optima for crude cellulase activity were pH 5 and $50{ }^{\circ} \mathrm{C}$, respectively. The crude cellulase retained approximately $50 \%$ and $26 \%$ of its activity at $48 \mathrm{~h}$ and $72 \mathrm{~h}$, respectively. P. oxalicum hydrolytic efficiency was comparable to commercial cellulase preparations and indicated its potential for lignocellulose hydrolysis application (Saini et al. 2015).

Aspergillus fumigatus isolated from chemically polluted microhabitats was reported for cellulase production with a maximum cellulase activity at $30 \%(\mathrm{v} / \mathrm{v})$ ionic liquids (ILs). Variations in the initial cellulase activity were observed in each IL, a longer half-life in most ILs than in buffer, with high conformational stability of the enzyme essential for sustaining the residual activity inappropriate media. Remarkably, $1-3 \mathrm{M} \mathrm{NaCl}$ can help in cellulase activation. A compatible IL-cellulase system based on the cellulase was reported with its use in significantly improving the rice straw saccharification rate from 53 to $88 \%$ as compared to the control, representing its effectiveness for the competent transformation of lignocellulose to glucose in a single-step process (Xu et al. 2014).

\section{Commercial cellulase availability and eminent market suppliers}

Cellulase has widespread applications in industries such as the paper and pulp industry, textile, food, and biorefinery. Some of the cellulase-producing companies on commercial scales are Novozymes (Denmark), Genencor-Danisco (Rochester, USA), DuPont (USA), Worthington Biochemical Corporation (Lakewood, USA), Dyadic (Jupiter, USA), Quest Intl. (Sarasota, Florida, USA), BASF (Germany), Kerry Group (Ireland), DSM (Netherlands), Chr. Hansen (Denmark), Rhom-AB enzymes (Rajamaki, Finland), Amano Enzyme Inc. (Nagoya, Aichi, Japan), Zhongbei Bio-Chem Industry Co., Ltd, (China) and Advanced Enzymes (India) (Markets and Markets 2020; Verardi et al. 2012). Some commercially available cellulases with their source and critical properties are tabulated in Table 5 .

The global cellulase market is spread worldwide, with a major focus in the Asia Pacific, Europe, the Middle East, and Africa, Latin America, and North America (TMR 2021). The increasing production and application of biofuel in North American and Latin American countries have projected them to be the leader in the market in the coming years (TMR 2021). Also, Asia Pacific regions with fast-growing economies like India and China can be viewed as a lucrative opportunity and expected to signal substantial market growth. The shift in focus from petrochemical-based refineries to bio-based biorefinery with greener technologies has increased application enzymes. These enzymes are lignocellulolytic, pectinolytic, amylolytic, and chitinolytic enzymes with the major 
Table 5 List of commercial cellulase producer and suppliers with its source and characteristics. Source: Verardi et al. (2012), and company's catalogue

\begin{tabular}{|c|c|c|c|c|}
\hline Commercial/market name & Company/supplier & Location/country & Source & Characteristics \\
\hline \multirow[t]{2}{*}{ Accellerase $^{\circledR} 1500$} & Genencor-Danisco & Rochester, USA & $\begin{array}{l}\text { Recombinant Trichoderma } \\
\text { reesei }\end{array}$ & $\begin{array}{l}\text { Endoglucanase: } 2200-2800 \mathrm{U} / \mathrm{g} \\
\beta \text {-Glucosidase: } 450-775 \mathrm{pNPG} \\
\mathrm{U} / \mathrm{g} \\
\text { Best operational stability at } \\
\text { temperature: } 50-65^{\circ} \mathrm{C} \text { and } \mathrm{pH} \text { : } \\
\text { 4.0-5.0 }\end{array}$ \\
\hline & DuPont Industrial Biosciences & USA & $\begin{array}{l}\text { Recombinant Trichoderma } \\
\text { reesei }\end{array}$ & $\begin{array}{l}\text { Cellulase: } 82 \mathrm{mg} / \mathrm{mL} \\
\text { Xylanase: } 51 \mathrm{mg} / \mathrm{mL}\end{array}$ \\
\hline Bio-feed beta $L$ & Novozymes & Bagsvaerd, Denmark & $\begin{array}{l}\text { T. longibrachiatum } \\
\text { T. reesei }\end{array}$ & $\begin{array}{l}\text { FPU: }<5 \mathrm{U} / \mathrm{mL} \\
\text { Cellobiases: } 12 \mathrm{U} / \mathrm{mL}\end{array}$ \\
\hline Biocellulase A & Quest Intl & Sarasota, Florida, USA & A. niger & $\begin{array}{l}\beta \text {-Glucosidase: } 32 \mathrm{Um} / \mathrm{L} \\
\text { High stability at pH } 5 \text { and } \\
\text { temperature } 55^{\circ} \mathrm{C}\end{array}$ \\
\hline Cellubrix (Celluclast) & Novozymes & Bagsvaerd, Denmark & $\begin{array}{l}\text { T. longibrachiatum } \\
\text { A. niger }\end{array}$ & $\begin{array}{l}\text { FPU: } 56 \mathrm{U} / \mathrm{mL} \\
\text { Cellobiases: } 136 \mathrm{U} / \mathrm{mL}\end{array}$ \\
\hline $\begin{array}{l}\text { Cellic CTec2 (cellulase, } \\
\text { enzyme blend) }\end{array}$ & Sigma Aldrich & Missouri, United States & $\begin{array}{l}\text { Trichoderma reesei } \\
\text { Aspergillus niger }\end{array}$ & Variable efficiency \\
\hline Cellulase 2000L & Rodhia-Danisco & Vinay, France & $\begin{array}{l}\text { T. longibrachiatum } \\
\text { T. reesei }\end{array}$ & FPU: $10 \mathrm{U} / \mathrm{mL}$ \\
\hline Cellulyve 50L & Lyven & $\begin{array}{l}\text { Colombelles } \\
\text { France }\end{array}$ & $\begin{array}{l}\text { T. longibrachiatum } \\
\text { T. reesei }\end{array}$ & FPU: $24 \mathrm{U} / \mathrm{mL}$ \\
\hline Cellulase AP $30 \mathrm{~K}$ & Amano Enzyme Inc & Nagoya, Aichi, Japan & A. niger & $\begin{array}{l}\beta \text {-Glucosidase: } 60 \mathrm{U} / \mathrm{mL} \\
\text { High stability at } \mathrm{pH} 4.5 \text { and } \\
\text { temperature } 60^{\circ} \mathrm{C}\end{array}$ \\
\hline Cellulase NLT 10,000 U/g & $\begin{array}{l}\text { Zhongbei Bio-Chem Industry } \\
\text { Co., Ltd }\end{array}$ & China & Trichoderma spp. & $\begin{array}{l}\text { Cellulase activity: } 10,000 \mathrm{U} / \mathrm{g} \\
\text { Optimum activity at } \mathrm{pH} 4.5 \text { and } \\
\text { temperature } 40-50^{\circ} \mathrm{C}\end{array}$ \\
\hline Energex L & Novozymes & Bagsvaerd, Denmark & $\begin{array}{l}\text { T. longibrachiatum } \\
\text { T. reesei }\end{array}$ & $\begin{array}{l}\text { FPU: }<5 \mathrm{U} / \mathrm{mL} \\
\text { Cellobiases: } 19 \mathrm{U} / \mathrm{mL}\end{array}$ \\
\hline GC220 & Genencor-Danisco & Rochester, USA & $\begin{array}{l}\text { T. longibrachiatum } \\
\text { T. reesei }\end{array}$ & $\begin{array}{l}\text { FPU: } 116 \mathrm{U} / \mathrm{mL} \\
\text { Cellobiases: } 215 \mathrm{U} / \mathrm{mL}\end{array}$ \\
\hline GC440 & Genencor-Danisco & Rochester, USA & $\begin{array}{l}\text { T. longibrachiatum } \\
\text { T. reesei }\end{array}$ & $\begin{array}{l}\text { FPU: }<5 \mathrm{U} / \mathrm{mL} \\
\text { Cellobiases: } 70 \mathrm{U} / \mathrm{mL}\end{array}$ \\
\hline GC880 & Genencor-Danisco & Rochester, USA & $\begin{array}{l}\text { T. longibrachiatum } \\
\text { T. reesei }\end{array}$ & $\begin{array}{l}\text { FPU: }<5 \mathrm{U} / \mathrm{mL} \\
\text { Cellobiases: } 86 \mathrm{U} / \mathrm{mL}\end{array}$ \\
\hline Novozymes 188 & Novozymes & Bagsvaerd, Denmark & A. niger & $\begin{array}{l}\mathrm{FPU}:<5 \mathrm{U} / \mathrm{mL} \\
\text { Cellobiases: } 1116 \mathrm{U} / \mathrm{mL}\end{array}$ \\
\hline Rohament $\mathrm{CL}$ & Rhom-AB Enzymes & Rajamäki, Finland & $\begin{array}{l}\text { T. longibrachiatum } \\
\text { T. reesei }\end{array}$ & $\begin{array}{l}\text { FPU: } 51 \mathrm{U} / \mathrm{mL} \\
\text { Cellobiases: } 28 \mathrm{U} / \mathrm{mL}\end{array}$ \\
\hline Spezyme CP & Genencor-Danisco & Rochester, USA & $\begin{array}{l}\text { T. longibrachiatum } \\
\text { T. reesei }\end{array}$ & FPU: $49 \mathrm{U} / \mathrm{mL}$ \\
\hline Ultraflo L & Novozymes & Bagsvaerd, Denmark & $\begin{array}{l}\text { T. longibrachiatum } \\
\text { T. reesei }\end{array}$ & $\begin{array}{l}\text { FPU: }<5 \mathrm{U} / \mathrm{mL} \\
\text { Cellobiases: } 20 \mathrm{U} / \mathrm{mL}\end{array}$ \\
\hline Viscozyme L & Novozymes & Bagsvaerd, Denmark & $\begin{array}{l}\text { T. longibrachiatum } \\
\text { T. reesei }\end{array}$ & $\begin{array}{l}\text { FPU: }<5 \mathrm{U} / \mathrm{mL} \\
\text { Cellobiases: } 23 \mathrm{U} / \mathrm{mL}\end{array}$ \\
\hline Viscostar 150L & Dyadic & Jupiter, USA & $\begin{array}{l}\text { T. longibrachiatum } \\
\text { T. reesei }\end{array}$ & $\begin{array}{l}\text { FPU: } 33 \mathrm{U} / \mathrm{mL} \\
\text { Cellobiases: } 111 \mathrm{U} / \mathrm{mL}\end{array}$ \\
\hline
\end{tabular}

market contribution of the cellulolytic enzyme (Kumar and Verma 2020a). This increase in demand is pushing researchers, academicians, government agencies, and industries to improve the yield and efficacy of cellulases.

\section{Techno-economic aspects of the cellulase production on large scale}

The cellulase applications in several industries, as discussed above and the challenge to retain the cost of enzyme production is an important parameter. Another critical factor is in controlling the economics 
of cellulase or enzyme reusability. Thus, a focus on developing the on-site production of cellulase using cheap lignocellulosic substrates has been suggested. Barta et al. (2010) studied the process design and economics of softwood-based ethanol plants, emphasizing on-site cellulase production utilizing different carbon sources. The study showed that in ethanol production at an industrial scale, the capital cost (0.42-0.53 SEK/L ethanol) is the main contributor, where $60-78 \%$ of the cost comes from enzyme production. Also, the study suggested that introduction of enzyme production step may cause a decrease in overall ethanol yield by $5-10 \mathrm{~L} /$ tonne, which was $270 \mathrm{~L} / \mathrm{dry}$ tonne of raw materials when the commercial enzyme was used. Further, the application of pretreatment before the use of biomass to cellulase production is suggested for enhanced cellulase production in a short incubation time. Barta et al. (2010) also demonstrated that pretreated liquid fraction supplemented with molasses could be an economical alternative in producing ethanol at a lower cost (4.71 and 4.82 SEK/L) (Fig. 4b).

Ferreira et al. (2021) analyzed the production cost of lignocellulose degrading enzymes and reveals that the most preferred organism and methods for lignocellulolytic enzyme productions are Trichoderma reesei (Teleomorph Hypocrea jecorina) and filamentous fungi using

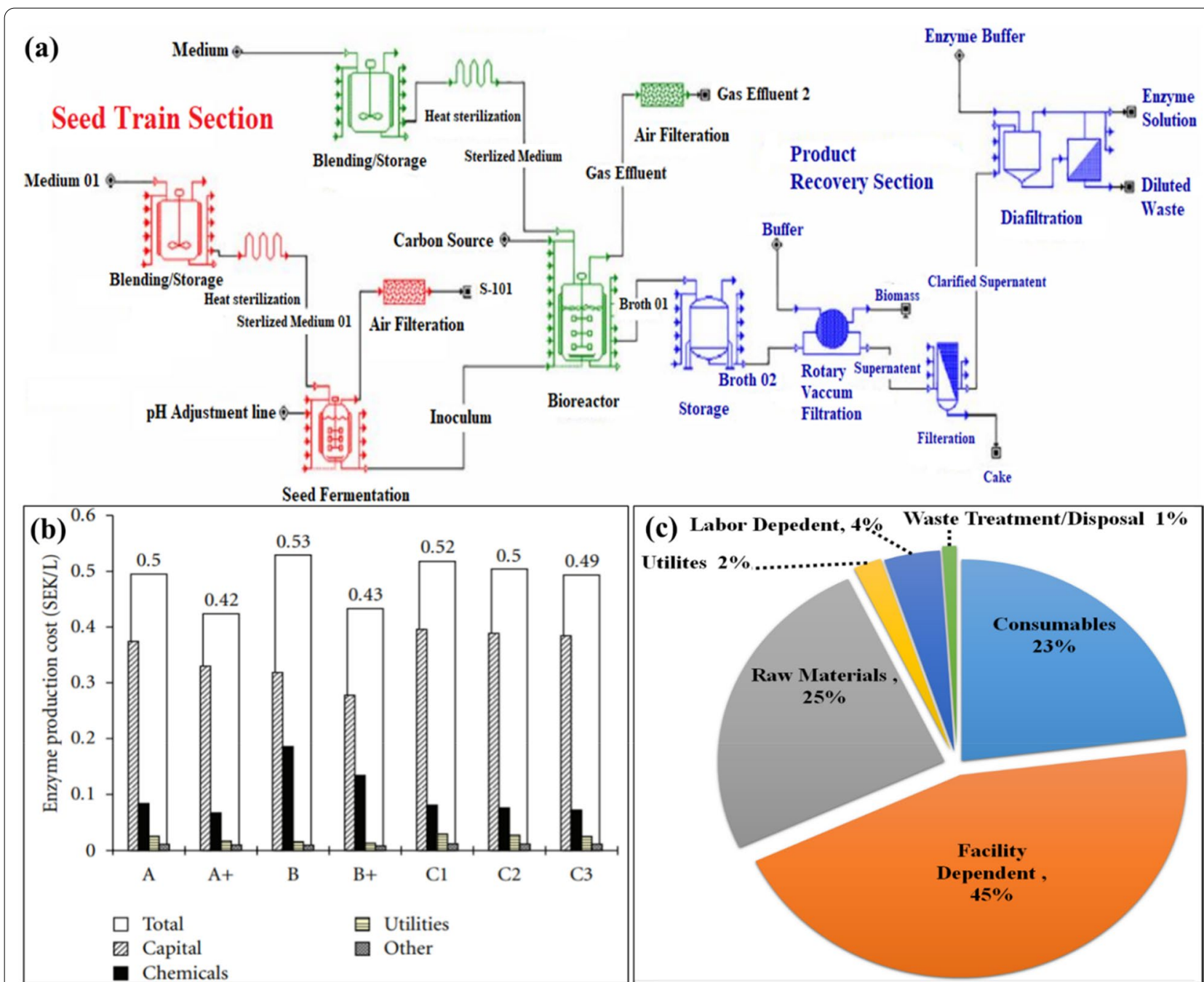

Fig. 4 Techno-economic aspect of cellulase production: a generic flowsheet of a cellulase production process with filamentous fungi [adapted with permission (Ferreira et al. 2021)]. b Cost contributors of enzyme production in (Swedish kronor) SEK/L ethanol. A, A+: pretreated liquid fraction, $\mathrm{B}, \mathrm{B}+$ : pretreated liquid fraction and molasses and $\mathrm{C} 1, \mathrm{C} 2, \mathrm{C} 3$ : pretreated liquid fraction and pressed pretreated slurry with a total WIS content of $1 \%, 2 \%$ and $3 \% ;+: 1.5$-fold specific activity (adapted from Barta et al. 2010). c Composition of the enzyme cost for recombinant $\beta$-glucosidase production using the baseline scenario (adapted and modified from Ferreira et al. 2018) 
submerged and SsF, respectively (Fig. 4a). The technoeconomic parameters evaluations suggested wide variation in cost on several process designs where the choice of raw materials/substrates and capital-related costs are generally the motor element of the enzyme production cost (Fig. 4c). The employment of low-cost medium utilizing cheaper and abundant raw materials such as agricultural and forestry residues can decrease the overall cost of enzyme production. Also, the production of auxiliary enzymes enhances the pretreatments and saccharification efficiency. The study suggested that other important parameters that are key to the economics of cellulase production are production titer, yield, and volumetric productivity.

The fungal sources of cellulase enzymes are used commercially, and supplementing the fungal enzymes with their lacking enzymatic activities can help in enhanced hydrolysis yield and subsequently help achieve low-cost hydrolysis (Ferreira et al. 2018). Ferreira et al. (2018) performed the techno-economic analysis of integrating $\beta$-glucosidase in a recombinant $E$. coli to industrialize a low-cost enzyme for their application in biorefinery (Fig. 4c). The major observations were that facility-dependent costs contribute significantly to the plant and recombinant enzyme production in E. coli is high compared to conventional methods. However, the cost of the enzyme could be reduced by using cheaper substrates, improve volumetric productivity and inoculation process apart from using a cheaper induction strategy. The E. coli strain is easy to handle at an industrial scale due to optimized upstream and streamlined downstream processes that help control the overall cost to produce the enzyme.

One of the limiting factors during cellulase-based enzymatic saccharification of lignocellulosic is unproductive adsorption of cellulases on lignin causing the reduction in enzyme activity (Gao et al. 2014; Siqueira et al. 2017). The addition of additives, e.g., non-ionic surfactant (tween) (Mukasekuru et al. 2018), polymer, e.g., polyethylene glycol (Arias et al. 2017), and non-catalytic protein, e.g., bovine serum albumin and soybean (Brondi et al. 2019, 2020) can help in overcoming the lignin mediated enzyme reduction and further results in enhanced enzyme activity at low enzyme load with high solid loading. The low cost and global abundance of soybean protein make it stand out lignin-blocking additive (KleinMarcuschamer et al. 2012; USDA 2021). Brondi et al. (2020) performed a retro-techno-economic analysis of the application of soybean protein as an additive during saccharification in an integrated (1G-2G) biorefinery. The study suggested that experimentally increasing biomass conversion (up to $80 \%$ ) and reducing enzyme loading to
5.6 FPU/g with soybean additive resulted in an economically integrated biorefinery.

Zhuang et al. (2007) demonstrated an economic assessment of the methodology, i.e., SsF and submerged fermentation $(\mathrm{SmF})$ used for the production of cellulase and its subsequent application in the conversion of fibrous biomass to bioethanol. The economic analysis suggested that the unit cost of cellulase production was around $\$ 15.67$ and $\$ 40.36$ per kilogram for the SSC and SmF, respectively. The deflation and inflation in the prices were calculated based on a factor of 0.9 and 1.1. Monte Carlo simulation-based sensitivity analysis suggested the unit cost of production using SSC is lower than SmF with high certainty of $99.6 \%$. Thus, suggesting SSC as a suitable low-cost in-house cellulase production methodology, thereby causing a reduction in overall ethanol production cost (Zhuang et al. 2007). The techno-economic survey of cellulosic biorefineries is recommended to adapt on-site co-production of lignocellulolytic enzymes using cheap agro-residues substrates (De Souza et al. 2021; Olofsson et al. 2015). Thus, this decrease in enzyme cost is expected to overcome the limitations of costly enzymes during saccharification in integrated biorefineries.

\section{Conclusion and future prospects}

Microbial cellulases obtained from LCB feedstock as a substrate is an efficient approach and can meet a high level of industrial demand. However, further studies are required to scale up cellulase production for the improved utilization of the strain at the industrial level. Future perspectives of the study may involve identifying new strains with the potential of multi-enzyme production and further developing pretreatment methods for effective utilization of lignocellulosic feedstocks. Identifying new genes from potential microorganisms for performing the genetic manipulations leads to improved catalytic property of cellulases. In addition, the development of inexpensive purification methodology at a large scale and molecular characterization of immobilized enzymes to increase its reusability and further kinetic parameter analysis of an immobilized enzyme can be an added advantage towards the industrialization of the bioconversion process. Also, as the enzyme production cost is key to its designated industrial application thus studies suggested that on-site co-production of multiple enzymes with emphasis on utilizing engineered strains and controlling process parameters are feasible methods for controlling the overall cost of the industry.

\section{Acknowledgements}

The authors are thankful to the Department of Biotechnology, Government of India, for providing the financial support (Grant Nos. BT/304/NE/TBP/2012 and BT/PR7333/PBD/26/373/2012). NB is thankful to the University Grants Commission (UGC) for providing fellowship for doctoral studies. BK is thankful to Jawaharlal Nehru Memorial Fund and Council of Scientific \& Industrial 
Research (CSIR) for providing scholarships and Senior Research Fellowship, respectively, for doctoral studies.

\section{Authors' contributions}

PV planned the paper and mentored NB to develop the manuscript. The paper used to develop the review was collected by PV, NB, and BK. Based on PV's inputs, suggestions, and recommendations, NB developed the rough draft of the manuscript. The rough draft was critically revised by BK and KA. Upon suggested revisions by the Journal, BK and NB have critically revised the MS. PV provided from time to time scientific and technical inputs to enhance the quality of the manuscript. The MS was finally reviewed and revised by PV to attain the present shape. PV acquired the necessary financial support for the projects leading to the publication. All authors read and approved the final manuscript.

\section{Funding}

Financial support from the Department of Biotechnology, Government of India, for providing the financial Grant Nos. BT/304/NE/TBP/2012 and BT/ PR7333/PBD/26/373/2012.

\section{Availability of data and materials}

Not applicable.

\section{Declarations}

\section{Ethics approval and consent to participate}

Not applicable.

\section{Consent for publication}

Not applicable.

\section{Competing interests}

The authors declare that they have no competing interests.

\section{Author details}

${ }^{1}$ Bioprocess and Bioenergy Laboratory, Department of Microbiology, Central University of Rajasthan, NH-8, Bandarsindri, Kishangarh, Ajmer, Rajasthan 305817, India. ${ }^{2}$ Department of Chemical Engineering, Institute of Chemical Technology, Nathalal Parekh Marg, Matunga, Mumbai, Maharashtra 400019, India.

Received: 12 July 2021 Accepted: 21 September 2021

Published online: 05 October 2021

\section{References}

Abbaszadeh M, Hejazi P (2019) Metal affinity immobilization of cellulase on $\mathrm{Fe}_{3} \mathrm{O}_{4}$ nanoparticles with copper as ligand for biocatalytic applications. Food Chem 290:47-55

Abraham RE, Verma ML, Barrow CJ, Puri M (2014) Suitability of magnetic nanoparticle immobilised cellulases in enhancing enzymatic saccharification of pretreated hemp biomass. Biotechnol Biofuels 7(90):1-12

Ahmad R, Khare SK (2018) Immobilization of Aspergillus niger cellulase on multiwall carbon nanotubes for cellulose hydrolysis. Bioresour Technol 252:72-75

Alexandri M, Schneider R, Papapostolou H, Ladakis D, Koutinas A, Venus J (2019) Restructuring the conventional sugar beet industry into a novel biorefinery: fractionation and bioconversion of sugar beet pulp into succinic acid and value-added coproducts. ACS Sustain Chem Eng 7(7):6569-6579

Ali SM, Omar SH, Soliman NA (2013) Co-production of cellulase and xylanase enzymes by thermophilic Bacillus subtilis 276NS. Int J Biotechnol Wellness Ind 2(2):65-74

Allardyce BJ, Linton SM, Saborowski R (2010) The last piece in the cellulase puzzle: the characterisation of $\beta$-glucosidase from the herbivorous gecarcinid land crab Gecarcoidea natalis. J Exp Biol 213(17):2950-2957

Almeida JR, Modig T, Petersson A, Hähn-Hägerdal B, Lidén G, GorwaGrauslund MF (2007) Increased tolerance and conversion of inhibitors in lignocellulosic hydrolysates by Saccharomyces cerevisiae. J Chem Technol Biotechnol 82(4):340-349

Alvira P, Tomás-Pejó E, Ballesteros M, Negro M (2010) Pretreatment technologies for an efficient bioethanol production process based on enzymatic hydrolysis: a review. Bioresour Technol 101(13):4851-4861

Amore A, Knott BC, Supekar NT, Shajahan A, Azadi P, Zhao P, Wells L, Linger JG, Hobdey SE, Vander Wall TA (2017) Distinct roles of N-and O-glycans in cellulase activity and stability. PNAS 114(52):13667-13672

André G, Kanchanawong P, Palma R, Cho H, Deng X, Irwin D, Himmel M, Wilson D, Brady J (2003) Computational and experimental studies of the catalytic mechanism of Thermobifida fusca cellulase Cel6A (E2). Protein Eng 16(2):125-134

Andrić P, Meyer AS, Jensen PA, Dam-Johansen K (2010) Reactor design for minimizing product inhibition during enzymatic lignocellulose hydrolysis: Il. Quantification of inhibition and suitability of membrane reactors. Biotechnol Adv 28(3):407-425

Ansari SA, Husain Q (2012) Potential applications of enzymes immobilized on/ in nano materials: a review. Biotechnol Adv 30(3):512-523

Ariaeenejad S, Motamedi E, Salekdeh GH (2020) Stable cellulase immobilized on graphene oxide CMC-g-poly (AMPS-Co-AAm) hydrogel for enhanced enzymatic hydrolysis of lignocellulosic biomass. Carbohydr Polym 230:115661

Arias JM, de Oliveira MA, Modesto LF, de Castro AM, Pereira N Jr (2017) Addition of surfactants and non-hydrolytic proteins and their influence on enzymatic hydrolysis of pretreated sugarcane bagasse. Appl Biochem Biotechnol 181(2):593-603

Ariffin H, Hassan MA, Shah UKM, Abdullah N, Ghazali FM, Shirai Y (2008) Production of bacterial endoglucanase from pretreated oil palm empty fruit bunch by Bacillus pumilus EB3. J Biosci Bioeng 106(3):231-236

Arnoul-Jarriault B, Lachenal D, Chirat C, Heux L (2015) Upgrading softwood bleached kraft pulp to dissolving pulp by cold caustic treatment and acid-hot caustic treatment. Ind Crops Prod 65:565-571

Avhad DN, Rathod VK (2015) Ultrasound-assisted production of a fibrinolytic enzyme in a bioreactor. Ultrason Sonochem 22:257-264

Azeredo H, Barud H, Farinas CS, Vasconcellos VM, Claro AM (2019) Bacterial cellulose as a raw material for food and food packaging applications. Front Sustain Food Syst 18(3):7

Bajaj BK, Pangotra H, Wani MA, Sharma P, Sharma A (2009) Partial purification and characterization of a highly thermostable and $\mathrm{pH}$ stable endoglucanase from a newly isolated Bacillus strain M-9. Int J Chem Technol 16:382-387

Banerjee G, Scott-Craig JS, Walton JD (2010) Improving enzymes for biomass conversion: a basic research perspective. Bioenergy Res 3(1):82-92

Barta Z, Kovacs K, Reczey K, Zacchi G (2010) Process design and economics of on-site cellulase production on various carbon sources in a softwoodbased ethanol plant. Enzyme Res 2010:734182

Bhardwaj N, Chanda K, Kumar B, Prasad HK, Sharma GD, Verma P (2017) Statistical optimization of nutritional and physical parameters for xylanase production from newly isolated Aspergillus oryzae LC1 and its application in the hydrolysis of lignocellulosic agro-residues. BioResources 12(4):8519-8538

Bhardwaj N, Kumar B, Agrawal K, Verma P (2019) Bioconversion of rice straw by synergistic effect of in-house produced ligno-hemicellulolytic enzymes for enhanced bioethanol production. Bioresour Technol Rep 10:100352

Bischof RH, Ramoni J, Seiboth B (2016) Cellulases and beyond: the first 70 years of the enzyme producer Trichoderma reesei. Microb Cell Factories 15(1):1-13

Boraston AB, Bolam DN, Gilbert HJ, Davies GJ (2004) Carbohydrate-binding modules: fine-tuning polysaccharide recognition. Biochem J 382(3):769-781

Branco A, Santos JDG, Pimentel MM, Osuna JT, Lima LS, David JM (2010) D-Mannitol from Agave sisalana biomass waste. Ind Crops Prod 32(3):507-510

Brondi MG, Elias AM, Furlan FF, Giordano RC, Farinas CS (2020) Performance targets defined by retro-techno-economic analysis for the use of soybean protein as saccharification additive in an integrated biorefinery. Sci Rep $10(1): 1-3$

Brondi MG, Vasconcellos VM, Giordano RC, Farinas CS (2019) Alternative low-cost additives to improve the saccharification of lignocellulosic biomass. Appl Biochem Biotechnol 187(2):461-473 
Cai LN, Xu SN, Lu T, Lin DQ, Yao SJ (2019) Salt-tolerant mechanism of marine Aspergillus niger cellulase cocktail and improvement of its activity. Chin J Chem Eng 28(4):1120-1128

Cao L (2005) Immobilised enzymes: science or art? Curr Opin Chem Biol 9(2):217-226

Cao L (2006) Carrier-bound immobilized enzymes: principles, application, and design. Wiley-VCH Verlag GmbH \& Co. KGaA, Weinheim

Cao L, Van Langen L, Sheldon RA (2003) Immobilised enzymes: carrier-bound or carrier-free? Curr Opin Biotechnol 14(4):387-394

Chakraborty S, Gaikwad A (2010) Mixing effects in cellulase-mediated hydrolysis of cellulose for bio-ethanol production. Ind Eng Chem Res 49(21):10818-10825

Chan YW, Acquah C, Obeng EM, Dullah EC, Jeevanandam J, Ongkudon CM (2019) Parametric study of immobilized cellulase-polymethacrylate particle for the hydrolysis of carboxymethyl cellulose. Biochimie 157:204-212

Chand P, Aruna A, Maqsood A, Rao L (2005) Novel mutation method for increased cellulase production. J Appl Microbiol 98(2):318-323

Chen Y, Wan J, Zhang X, Ma Y, Wang Y (2012) Effect of beating on recycled properties of unbleached eucalyptus cellulose fiber. Carbohydr Polym 87(1):730-736

Chen F, Zhang X, Du X, Yang L, Zu Y, Yang F (2016) A new approach for obtaining trans-resveratrol from tree peony seed oil extracted residues using ionic liquid-based enzymatic hydrolysis in situ extraction. Sep Purif Technol 170:294-305

Chen QY, Ma XJ, Li JG, Miao QX, Huang LL (2017) Effect of the utilization of electron beam irradiation on the reactivity of bamboo dissolving pulp. BioResources 12(3):6251-6261

Chen G, Sui X, Liu T, Wang H, Zhang J, Sun J, Xu T (2018a) Application of cellulase treatment in ionic liquid based enzyme-assisted extraction in combine with in-situ hydrolysis process for obtaining genipin from Eucommia ulmoides Olive barks. J Chromatogr A 1569:26-35

Chen Q, Liu D, Wu C, Yao K, Li Z, Shi N, Wen F, Gates ID (2018b) Co-immobilization of cellulase and lysozyme on amino-functionalized magnetic nanoparticles: an activity-tunable biocatalyst for extraction of lipids from microalgae. Bioresour Technol 263:317-324

Cheng S, Yang P, Guo L, Lin J, Lou N (2009) Expression of multi-functional cellulase gene mfc in Coprinus cinereus under control of different basidiomycete promoters. Bioresour Technol 100(19):4475-4480

Cherian E, Dharmendirakumar M, Baskar G (2015) Immobilization of cellulase onto $\mathrm{MnO}_{2}$ nanoparticles for bioethanol production by enhanced hydrolysis of agricultural waste. Chin J Catal 36(8):1223-1229

Chukwuma OB, Rafatullah M, Tajarudin HA, Ismail N (2020) Lignocellulolytic enzymes in biotechnological and industrial processes: a review. Sustainability $12(18): 7282$

Chundawat SP, Bellesia G, Uppugundla N, da Costa Sousa L, Gao D, Cheh AM, Agarwal UP, Bianchetti CM, Phillips GN Jr, Langan P (2011) Restructuring the crystalline cellulose hydrogen bond network enhances its depolymerization rate. J Am Chem Soc 133(29):11163-11174

Colla LM, Primaz AL, Benedetti S, Loss RA, de Lima M, Reinehr CO, Bertolin TE, Costa JAV (2016) Surface response methodology for the optimization of lipase production under submerged fermentation by filamentous fungi. Braz J Microbiol 47(2):461-467

Combier JP, Melayah D, Raffier C, Gay G, Marmeisse R (2003) Agrobacterium tumefaciens-mediated transformation as a tool for insertional mutagenesis in the symbiotic ectomycorrhizal fungus Hebeloma cylindrosporum. FEMS Microbiol Lett 220(1):141-148

Crognale S, Liuzzi F, D'Annibale A, de Bari I, Petruccioli M (2019) Cynara cardunculus a novel substrate for solid-state production of Aspergillus tubingensis cellulases and sugar hydrolysates. Biomass Bioenergy 127:105276

Cruys-Bagger N, Tatsumi H, Ren GR, Borch K, Westh P (2013) Transient kinetics and rate-limiting steps for the processive cellobiohydrolase Cel7A: effects of substrate structure and carbohydrate binding domain. Biochemistry 52(49):8938-8948

Cui JD, Jia SR (2015) Optimization protocols and improved strategies of cross-linked enzyme aggregates technology: current development and future challenges. Crit Rev Biotechnol 35(1):15-28

Cunha F, Esperanca M, Zangirolami T, Badino A, Farinas C (2012) Sequential solid-state and submerged cultivation of Aspergillus niger on sugarcane bagasse for the production of cellulase. Bioresour Technol 112:270-274
Dadheech T, Shah R, Pandit R, Hinsu A, Chauhan PS, Jakhesara S, Kunjadiya A, Rank D, Joshi C (2018) Cloning, molecular modeling and characterization of acidic cellulase from buffalo rumen and its applicability in saccharification of lignocellulosic biomass. Int J Biol Macromol 113:73-81

Dadwal A, Sharma S, Satyanarayana T (2020) Progress in ameliorating beneficial characteristics of microbial cellulases by genetic engineering approaches for cellulose saccharification. Front Microbiol 24(11):1387

Dal Magro L, Silveira VC, de Menezes EW, Benvenutti EV, Nicolodi S, Hertz PF, Klein MP, Rodrigues RC (2018) Magnetic biocatalysts of pectinase and cellulase: synthesis and characterization of two preparations for application in grape juice clarification. Int J Biol Macromol 115:35-44

Dar MA, Pawar KD, Rajput BP, Rahi P, Pandit RS (2019) Purification of a cellulase from cellulolytic gut bacterium, Bacillus tequilensis $\mathrm{G} 9$ and its evaluation for valorization of agro-wastes into added value byproducts. Biocatal Agric Biotechnol 20:101219

Davison SA, Den Haan R, van ZyI WH (2016) Heterologous expression of cellulase genes in natural Saccharomyces cerevisiae strains. Appl Microbiol Biotechnol 100(18):8241-8254

Davison SA, den Haan R, van Zyl WH (2019a) Identification of superior cellulase secretion phenotypes in haploids derived from natural Saccharomyces cerevisiae isolates. FEMS Yeast Res 19:foy 117

Davison SA, Keller NT, van Zyl WH, den Haan R (2019b) Improved cellulase expression in diploid yeast strains enhanced consolidated bioprocessing of pretreated corn residues. Enzyme Microb Technol 131:109382

De Castro RJS, Sato HH (2015) Enzyme production by solid state fermentation: general aspects and an analysis of the physicochemical characteristics of substrates for agro-industrial wastes valorization. Waste Biomass Valoriz 6(6):1085-1093

De Almeida MN, Falkoski DL, Guimarães VM, de Rezende ST (2019) Study of gamba grass as carbon source for cellulase production by Fusarium verticillioides and its application on sugarcane bagasse saccharification. Ind Crops Prod 133:33-43

De Souza Melchiors M, Veneral JG, Junior AF, de Oliveira JV, Di Luccio M, Prando LT, Terenzi H, de Oliveira D (2017) Effect of compressed fluids on the enzymatic activity and structure of lysozyme. J Supercrit Fluids 130:125-132

De Souza MF, da Silva Bon EP, da Silva AS (2021) Production of cellulases and $\beta$-glucosidases by Trichoderma reesei Rut C30 using steam-pretreated sugarcane bagasse: an integrated approach for onsite enzyme production. Braz J Chem Eng 25:1-8

Delgado-Povedano M, De Castro ML (2015) A review on enzyme and ultrasound: a controversial but fruitful relationship. Anal Chim Acta 889:1-21

Den Haan R, Van Zyl JM, Harms TM, van Zyl WH (2013) Modeling the minimum enzymatic requirements for optimal cellulose conversion. Environ Res Lett 8:025013

Den Haan R, Van Rensburg E, Rose SH, Görgens JF, Van Zyl WH (2015) Progress and challenges in the engineering of non-cellulolytic microorganisms for consolidated bioprocessing. Curr Opin Biotechnol 33:32-38

Desai MP, Pawar KD (2020) Immobilization of cellulase on iron tolerant Pseudomonas stutzeri biosynthesized photocatalytically active magnetic nanoparticles for increased thermal stability. Mat Sci Eng C 106:110169

Dhillon GS, Kaur S, Brar SK, Verma M (2012) Potential of apple pomace as a solid substrate for fungal cellulase and hemicellulase bioproduction through solid-state fermentation. Ind Crops Prod 38:6-13

Dijkstra Z, Merchant R, Keurentjes J (2007) Stability and activity of enzyme aggregates of Calb in supercritical $\mathrm{CO}_{2}$. J Supercrit Fluids 41(1):102-108

Ding SY, XU Q, Crowley M, Zeng Y, Nimlos M, Lamed R, Bayer EA, Himmel ME (2008) A biophysical perspective on the cellulosome: new opportunities for biomass conversion. Curr Opin Biotechnol 19(3):218-227

Doi RH, Kosugi A (2004) Cellulosomes: plant-cell-wall-degrading enzyme complexes. Nat Rev Microbiol 2(7):541-551

Dong RJ, Zheng DF, Yang DJ, Qiu XQ (2019) pH-responsive lignin-based magnetic nanoparticles for recovery of cellulase. Bioresour Technol 294:122133

Ejaz U, Muhammad S, Hashmi IA, Ali Fl, Sohail M (2020) Utilization of methyltrioctylammonium chloride as new ionic liquid in pretreatment of sugarcane bagasse for production of cellulase by novel thermophilic bacteria. J Biotechnol 317:34-38

Ellilä S, Fonseca L, Uchima C, Cota J, Goldman GH, Saloheimo M, Sacon V, SiikaAho M (2017) Development of a low-cost cellulase production process 
using Trichoderma reesei for Brazilian biorefineries. Biotechnol Biofuels 10(30):1-17

Engström AC, Ek M, Henriksson G (2006) Improved accessibility and reactivity of dissolving pulp for the viscose process: pretreatment with monocomponent endoglucanase. Biomacromol 7(6):2027-2031

Ezat AA, El-Bialy NS, Mostafa HI, Ibrahim MA (2014) Molecular docking investigation of the binding interactions of macrocyclic inhibitors with $\mathrm{HCV}$ NS3 protease and its mutants (R155K, D168A and A156V). Protein J 33(1):32-47

Ezeilo UR, Lee CT, Huyop F, Zakaria II, Wahab RA (2019a) Raw oil palm frond leaves as cost-effective substrate for cellulase and xylanase productions by Trichoderma asperellum UC1 under solid-state fermentation. J Environ Manag 243:206-217

Ezeilo UR, Wahab RA, Mahat NA (2019b) Optimization studies on cellulase and xylanase production by Rhizopus oryzae UC2 using raw oil palm frond leaves as substrate under solid state fermentation. Renew Energy 156:1301-1312

Fang $\mathrm{G}$, Chen $\mathrm{H}$, Zhang Y, Chen A (2016) Immobilization of pectinase onto $\mathrm{Fe}_{3} \mathrm{O}_{4} @ \mathrm{SiO}_{2}-\mathrm{NH}_{2}$ and its activity and stability. Int J Biol Macromol 88:189-195

Ferreira RDG, Azzoni AR, Freitas S (2018) Techno-economic analysis of the industrial production of a low-cost enzyme using $E$. coli: the case of recombinant $\beta$-glucosidase. Biotechnol Biofuels 11(1):1-13

Ferreira RG, Azzoni AR, Freitas S (2021) On the production cost of lignocellulose-degrading enzymes. Biofuel Bioprod Biorefin 15(1):85-99

Fujii T, Murakami K, Sawayama S (2010) Cellulase hyperproducing mutants derived from the fungus Trichoderma reesei QM9414 produced large amounts of cellulase at the enzymatic and transcriptional levels. Biosc Biotechnol Biochem 74(2):419-422

Fujita Y, Ito J, Ueda M, Fukuda H, Kondo A (2004) Synergistic saccharification, and direct fermentation to ethanol, of amorphous cellulose by use of an engineered yeast strain codisplaying three types of cellulolytic enzyme. Appl Environ Microbiol 70(2):1207-1212

Gao ZH, Xu GJ, Zhao FK (2007) Expression of a multi-functional endogenous cellulase gene from mollusc, Ampullaria crossean in Saccharomyces Cerevisiae. J Zhejiang Univ Sci 4:479-482

Gao D, Haarmeyer C, Balan V, Whitehead TA, Dale BE, Chundawat SP (2014) Lignin triggers irreversible cellulase loss during pretreated lignocellulosic biomass saccharification. Biotechnol Biofuels 7(1):1-3

Garcia-Galan C, Berenguer-Murcia Á, Fernandez-Lafuente R, Rodrigues RC (2011) Potential of different enzyme immobilization strategies to improve enzyme performance. Adv Synth Catal 353(16):2885-2904

Gasser B, Saloheimo M, Rinas U, Dragosits M, Rodríguez-Carmona E, Baumann K, Giuliani M, Parrilli E, Branduardi P, Lang C (2008) Protein folding and conformational stress in microbial cells producing recombinant proteins: a host comparative overview. Microb Cell Fact 7(1):1-18

Gehring AM, Nodwell JR, Beverley SM, Losick R (2000) Genomewide insertional mutagenesis in Streptomyces coelicolor reveals additional genes involved in morphological differentiation. Proc Natl Acad Sci 97(17):9642-9647

Ghadiri E, Naghavi NS, Ghaedi K (2020) Molecular cloning and characterizing of Bacillus subtilis cellulase collected from central-northern Iran forests. Gene Rep 20:100772

Goja AM, Yang H, Cui M, Li C (2013) Aqueous two-phase extraction advances for bioseparation. J Bioprocess Biotechnol 4(1):1-8

Gokhale AA, Lu J, Lee I (2013) Immobilization of cellulase on magnetoresponsive graphene nano-supports. J Mol Catal B Enzym 90:76-86

Goldbeck R, Ramos MM, Pereira GA, Maugeri-Filho F (2013) Cellulase production from a new strain Acremonium strictum isolated from the Brazilian Biome using different substrates. Bioresour Technol 128:797-803

Gomes D, Rodrigues AC, Domingues L, Gama M (2015) Cellulase recycling in biorefineries—is it possible? Appl Microbiol Biotechnol 99(10):4131-4143

Granado J, Kertesz-Chaloupková K, Aebi M, Kües U (1997) Restriction enzymemediated DNA integration in Coprinus cinereus. Mol Gen Genet 256(1):28-36

Grewal J, Ahmad R, Khare S (2017) Development of cellulase-nanoconjugates with enhanced ionic liquid and thermal stability for in situ lignocellulose saccharification. Bioresour Technol 242:236-243

Guisan JM (2006) Immobilization of enzymes and cells. Springer, New York
Guldhe A, Singh B, Renuka N, Singh P, Misra R, Bux F (2017) Bioenergy: a sustainable approach for cleaner environment. Phytoremediation potential of bioenergy plants. Springer, Singapore, pp 47-62

Gupta P, Samant K, Sahu A (2012) Isolation of cellulose-degrading bacteria and determination of their cellulolytic potential. Int J Microbiol 2012:578925

Gusakov AV, Salanovich TN, Antonov Al, Ustinov BB, Okunev ON, Burlingame R, Emalfarb M, Baez M, Sinitsyn AP (2007) Design of highly efficient cellulase mixtures for enzymatic hydrolysis of cellulose. Biotechnol Bioeng 97(5):1028-1038

Han J, Wang L, Wang Y, Dong J, Tang X, Ni L, Wang L (2018) Preparation and characterization of $\mathrm{Fe}_{3} \mathrm{O}_{4}-\mathrm{NH}_{2}$ 4-arm-PEG- $\mathrm{NH}_{2}$, a novel magnetic four-arm polymer-nanoparticle composite for cellulase immobilization. Chem Eng J 130:90-98

Hansen GH, Lübeck M, Frisvad JC, Lübeck PS, Andersen B (2015) Production of cellulolytic enzymes from ascomycetes: comparison of solid state and submerged fermentation. Process Biochem 50(9):1327-1341

Harris PV, Xu F, Kreel NE, Kang C, Fukuyama S (2014) New enzyme insights drive advances in commercial ethanol production. Curr Opin Chem Biol 19:162-170

Harshvardhan K, Mishra A, Jha B (2013) Purification and characterization of cellulase from a marine Bacillus sp. H1666: a potential agent for single step saccharification of seaweed biomass. J Mol Catal B Enzym 93:51-56

Hasunuma T, Okazaki F, Okai N, Hara KY, Ishii J, Kondo A (2013) A review of enzymes and microbes for lignocellulosic biorefinery and the possibility of their application to consolidated bioprocessing technology. Bioresour Technol 135:513-522

He M, Yang G, Chen J, Ji X, Wang Q (2018) Production and characterization of cellulose nanofibrils from different chemical and mechanical pulps. J Wood Chem Technol 38(2):149-158

Herpoël-Gimbert I, Margeot A, Dolla A, Jan G, Mollé D, Lignon S, Mathis H, Sigoillot J-C, Monot F, Asther M (2008) Comparative secretome analyses of two Trichoderma reesei RUT-C30 and CL847 hypersecretory strains. Biotechnol Biofuels 1(1):1-12

Hirayama K, Watanabe H, Tokuda G, Kitamoto K, Arioka M (2010) Purification and characterization of termite endogenous $\beta$-1, 4-endoglucanases produced in Aspergillus oryzae. Biosci Biotechnol Biochem 74(8):1680-1686

Ho SL, Lan JCW, Tan JS, Yim HS, Ng HS (2017) Aqueous biphasic system for the partial purification of Bacillus subtilis carboxymethyl cellulase. Process Biochem 58:276-281

Hofman M, Thonart P (2001) Engineering and manufacturing for biotechnology. Springer, Dordrecht

Hou R, Hu J, Wang Y, Wei H, Gao MT (2020) Simultaneous production of celIulase and ferulic acid esterase by Penicillium decumbens with rice straw as the sole carbon source. J Biosci Bioeng 129(3):276-283

Huang SY, Zou X (2010) Advances and challenges in protein-ligand docking. Int J Mol Sci 11(8):3016-3034

Hyeon JE, Shin SK, Han SO (2016) Design of nanoscale enzyme complexes based on various scaffolding materials for biomass conversion and immobilization. Biotechnol J 11(11):1386-1396

Ibarra D, Köpcke V, Ek M (2010) Behavior of different monocomponent endoglucanases on the accessibility and reactivity of dissolving-grade pulps for viscose process. Enzyme Microb Technol 47(7):355-362

Igarashi K, Wada M, Samejima M (2007) Activation of crystalline cellulose to cellulose IIII results in efficient hydrolysis by cellobiohydrolase. FEBS J 274(7):1785-1792

Ike M, Park JY, Tabuse M, Tokuyasu K (2010) Cellulase production on glucosebased media by the UV-irradiated mutants of Trichoderma reesei. Appl Microbiol Biotechnol 87(6):2059-2066

Irshad M, Murtza A, Zafar M, Bhatti KH, Rehman A, Anwar Z (2017) Chitosanimmobilized pectinolytics with novel catalytic features and fruit juice clarification potentialities. Int J Biol Macromol 104:242-250

Jalal J, Leong TS (2018) Microstreaming and its role in applications: a minireview. Fluids 3(93):1-13

Jampala P, Tadikamalla S, Preethi M, Ramanujam S, Uppuluri KB (2017) Concurrent production of cellulase and xylanase from Trichoderma reesei NCIM 1186: enhancement of production by desirability-based multi-objective method. 3 Biotech 7(14):1-13

Jayasekara S, Ratnayake R (2019) Microbial cellulases: an overview and applications. Cellulose 2(22):1-21 
Jeon J, Park SY, Chi MH, Choi J, Park J, Rho HS, Kim S, Goh J, Yoo S, Choi J (2007) Genome-wide functional analysis of pathogenicity genes in the rice blast fungus. Nat Genet 39(4):561-565

Jeong DH, An S, Kang HG, Moon S, Han JJ, Park S, Lee HS, An K, An G (2002) T-DNA insertional mutagenesis for activation tagging in rice. Plant Physiol 130(4):1636-1644

Juturu V, Wu JC (2014a) Microbial cellulases: engineering, production and applications. Renew Sustain Energy Rev 33:188-203

Juturu V, Wu JC (2014b) Microbial exo-xylanases: a mini review. Appl Biochem Biotechnol 174(1):81-92

Kamal T, Ahmad I, Khan SB, Asiri AM (2019) Anionic polysaccharide stabilized nickel nanoparticles-coated bacterial cellulose as a highly efficient dipcatalyst for pollutants reduction. React Funct Polym 145:104395

Kewcharoen W, Srisapoome P (2019) Probiotic effects of Bacillus spp. from Pacific white shrimp (Litopenaeus vannamei) on water quality and shrimp growth, immune responses, and resistance to Vibrio parahaemolyticus (AHPND strains). Fish Shellfish Immunol 94:175-189

Kim N, Choo YM, Lee KS, Hong SJ, Seol KY, Je YH, Sohn HD, Jin BR (2008) Molec ular cloning and characterization of a glycosyl hydrolase family 9 cellulase distributed throughout the digestive tract of the cricket Teleogryllus emma. Comp Biochem Physiol B Biochem Mol Biol 150(4):368-376

Klein-Marcuschamer D, Oleskowicz-Popiel P, Simmons BA, Blanch HW (2012) The challenge of enzyme cost in the production of lignocellulosic biofuels. Biotechnol Bioeng 109(4):1083-1087

Krajewska B (2004) Application of chitin-and chitosan-based materials for enzyme immobilizations: a review. Enzyme Microb Technol 35(2-3):126-139

Kristensen JB, Felby C, Jørgensen H (2009) Determining yields in high solids enzymatic hydrolysis of biomass. Appl Biochem Biotechnol 156(1-3):127-132

Kroukamp H, Den Haan R, Van Wyk N, Van Zyl WH (2013) Overexpression of native PSE1 and SOD1 in Saccharomyces cerevisiae improved heterologous cellulase secretion. Appl Energy 102:150-156

Kucharska K, Rybarczyk P, Hołowacz l, Łukajtis R, Glinka M, Kamiński M (2018) Pretreatment of lignocellulosic materials as substrates for fermentation processes. Molecules 23(11):2937

Kumar N (2009) Studies of glucose oxidase immobilized carbon nanotubepolyaniline composites, MSc. thesis. Thapar University, Patiala (India)

Kumar H, Christopher LP (2017) Recent trends and developments in dissolving pulp production and application. Cellulose 24(6):2347-2365

Kumar B, Verma P (2020a) Enzyme mediated multi-product process: a concept of bio-based refinery. Ind Crops Prod 154:112607

Kumar B, Verma P (2020b) Application of hydrolytic enzymes in biorefinery and its future prospects. Microbial strategies for techno-economic biofuel production. Springer, Singapore, pp 59-83

Kumar R, Singh S, Singh OV (2008) Bioconversion of lignocellulosic biomass: biochemical and molecular perspectives. I Ind Microbiol Biotechnol 35(5):377-391

Kumar B, Bhardwaj N, Alam A, Agrawal K, Prasad H, Verma P (2018) Production, purification and characterization of an acid/alkali and thermo tolerant cellulase from Schizophyllum commune NAIMCC-F-03379 and its application in hydrolysis of lignocellulosic wastes. AMB Express 8(173):1-16

Kumar S, Morya V, Gadhavi J, Vishnoi A, Singh J, Datta B (2019) Investigation of nanoparticle immobilized cellulase: nanoparticle identity, linker length and polyphenol hydrolysis. Heliyon 5:e01702

Kunitake E, Kobayashi T (2017) Conservation and diversity of the regulators of cellulolytic enzyme genes in Ascomycete fungi. Curr Genet 63(6):951-958

Ladole MR, Mevada JS, Pandit AB (2017) Ultrasonic hyperactivation of cellulase immobilized on magnetic nanoparticles. Bioresour Technol 239:117-126

Lambertz C, Garvey M, Klinger J, Heesel D, Klose H, Fischer R, Commandeur $U$ (2014) Challenges and advances in the heterologous expression of cellulolytic enzymes: a review. Biotechnol Biofuels 7(135):1-15

Lan TQ, Wei D, Yang ST, Liu X (2013) Enhanced cellulase production by Trichoderma viride in a rotating fibrous bed bioreactor. Bioresour Technol 133:175-182

Laurent S, Forge D, Port M, Roch A, Robic C, Vander Elst L, Muller RN (2008) Magnetic iron oxide nanoparticles: synthesis, stabilization, vectorization, physicochemical characterizations, and biological applications Chem Rev 108(6):2064-2110
Li WY, Wang J, Li YH, Ding M, Xu GJ, Liu LY, Zhao FK (2004) pH-dependent stability of EGX, a multi-functional cellulase from mollusca. Ampullaria Crossean Acta Biochim Biophys Sin 36(9):603-608

Li YL, Li H, Li AN, Li DC (2009) Cloning of a gene encoding thermostable cellobiohydrolase from the thermophilic fungus Chaetomium thermophilum and its expression in Pichia pastoris. J Appl Microbiol 106:1867-1875

Li BF, Zhu YX, Gu ZB, Yuan C, Jing L, Xiao G, Li F, Qing L, Xi DM, Mao HM (2016a) Screening and characterization of a novel ruminal cellulase gene (Umcel-1) from a metagenomic library of gayal (Bos frontalis). J Integr Agr 15(4):855-861

Li J, Ma X, Duan C, Liu Y, Zhang H, Ni Y (2016b) Enhanced removal of hemicelluloses from cellulosic fibers by poly (ethylene glycol) during alkali treatment. Cellulose 23(1):231-238

Li Y, Zhang X, Xiong L, Mehmood MA, Zhao X, Bai F (2017a) On-site cellulase production and efficient saccharification of corn stover employing cbh2 overexpressing Trichoderma reesei with novel induction system. Bioresour Technol 238:643-649

Li Z, Liu G, Qu Y (2017b) Improvement of cellulolytic enzyme production and performance by rational designing expression regulatory network and enzyme system composition. Bioresour Technol 245:1718-1726

Li J, Zhang S, Li H, Huang K, Zheng L, Ouyang X, Zheng Q, Huang L, Chen L, Ni Y (2018a) A new approach to improve dissolving pulp properties: spraying cellulase on rewetted pulp at a high fiber consistency. Cellulose 25(12):6989-7002

Li Q, Al Loman A, Callow NV, Islam SM, Ju LK (2018b) Leveraging pH profiles to direct enzyme production (cellulase, xylanase, polygalacturonase, pectinase, a-galactosidase, and invertase) by Aspergillus foetidus. Biochem Eng J 137:247-254

Li C, Li D, Feng J, Fan X, Chen S, Zhang D, He R (2019) Duckweed (Lemna minor) is a novel natural inducer of cellulase production in Trichoderma reesei. J Biosci Bioeng 127(4):486-491

Li F, Xie Y, Gao X, Shan M, Sun C, Niu YD, Shan A (2020) Screening of cellulose degradation bacteria from Min pigs and optimization of its cellulase production. Electron J Biotechnol 1(48):29-35

Liang W, Cao X (2012) Preparation of a pH-sensitive polyacrylate amphiphilic copolymer and its application in cellulase immobilization. Bioresour Technol 116:140-146

Liang L, Xue D (2017) Kinetics of cellulose hydrolysis by halostable cellulase from a marine Aspergillus niger at different salinities. Process Biochem 63:163-168

Liao H, Chen D, Yuan L, Zheng M, Zhu Y, Liu X (2010) Immobilized cellulase by polyvinyl alcohol/ $/ \mathrm{Fe}_{2} \mathrm{O}_{3}$ magnetic nanoparticle to degrade microcrystalline cellulose. Carbohydr Polym 82(3):600-604

Libardi N, Soccol CR, Góes-Neto A, de Oliveira J, de Souza Vandenberghe LP (2017) Domestic wastewater as substrate for cellulase production by Trichoderma harzianum. Process Biochem 57:190-199

Lima JS, Araújo PH, Sayer C, Souza AA, Viegas AC, de Oliveira D (2017) Cellulase immobilization on magnetic nanoparticles encapsulated in polymer nanospheres. Bioprocess Biosyst Eng 40(4):511-518

Lin J, Zheng M, Wang J, Shu W, Guo L (2008) Efficient transformation and expression of gfp gene in the edible mushroom Pleurotus nebrodensis. Prog Nat Sci 18(7):819-824

Linder M, Teeri TT (1997) The roles and function of cellulose-binding domains.J Biotechnol 57(1-3):15-28

Liu JH, Tsai CF, Liu JW, Cheng KJ, Cheng CL (2001) The catalytic domain of a Piromyces rhizinflata cellulase expressed in Escherichia coli was stabilized by the linker peptide of the enzyme. Enzyme Microb Technol 28(7-8):582-589

Liu D, Zhang R, Yang X, Wu H, Xu D, Tang Z, Shen Q (2011) Thermostable cellulase production of Aspergillus fumigatus $Z 5$ under solid-state fermentation and its application in degradation of agricultural wastes. Int Biodeter Biodegr 65(5):717-725

Liu Y, Sun B, Zheng X, Yu L, Li J (2018) Integrated microwave and alkaline treatment for the separation between hemicelluloses and cellulose from cellulosic fibers. Bioresour Technol 247:859-863

Lo N, Tokuda G, Watanabe H, Rose H, Slaytor M, Maekawa K, Bandi C, Noda $\mathrm{H}$ (2000) Evidence from multiple gene sequences indicates that termites evolved from wood-feeding cockroaches. Curr Biol 10(13):801-804 
Lodha A, Pawar S, Rathod V (2020) Optimised cellulase production from fungal co-culture of Trichoderma reesei NCIM 1186 and Penicillium citrinum NCIM 768 under solid state fermentation. J Environ Chem Eng 8:103958

Lombard V, Golaconda Ramulu H, Drula E, Coutinho PM, Henrissat B (2014) The carbohydrate-active enzymes database (CAZy) in 2013. Nucleic Acids Res 42(D1):D490-D495

Lopes AD, Ferreira Filho EX, Moreira LR (2018) An update on enzymatic cocktails for lignocellulose breakdown. J Appl Microbiol 125(3):632-645

Lü R, Zhao A, Li J, Liu C, Wang C, Wang X, Wang X, Pei R, Lu C, Yu M (2015) Screening, cloning and expression analysis of a cellulase derived from the causative agent of hypertrophy sorosis scleroteniosis, Ciboria shiraiana. Gene 565(2):221-227

Lucio VD, Susana B, Hernández-Domínguez EM, Villa-García M, Díaz-Godínez G, Mandujano-Gonzalez V, Mendoza-Mendoza B, Álvarez-Cervantes J (2021) Exogenous enzymes as zootechnical additives in animal feed: a review. Catalysts 11(7):851

Lynd LR, Weimer PJ, Van Zyl WH, Pretorius IS (2002) Microbial cellulose utilization: fundamentals and biotechnology. Microbiol Mol Biol Rev 66(3):506-577

Lynd LR, Laser MS, Bransby D, Dale BE, Davison B, Hamilton R, Himmel M, Keller M, McMillan JD, Sheehan J (2008) How biotech can transform biofuels. Nat Biotechnol 26(2):169-172

Lynd LR, Liang X, Biddy MJ, Allee A, Cai H, Foust T, Himmel ME, Laser MS, Wang M, Wyman CE (2017) Cellulosic ethanol: status and innovation. Curr Opin Biotechnol 45:202-211

Ma L, Zhang J, Zou G, Wang C, Zhou Z (2011) Improvement of cellulase activity in Trichoderma reesei by heterologous expression of a betaglucosidase gene from Penicillium decumbens. Enzyme Microb Technol 49(4):366-371

Maeda RN, Barcelos CA, Santa Anna LMM, Pereira N Jr (2013) Cellulase production by Penicillium funiculosum and its application in the hydrolysis of sugar cane bagasse for second generation ethanol production by fed batch operation. J Biotechnol 163(1):38-44

Marín-Navarro J, Gurgu L, Alamar S, Polaina J (2011) Structural and functional analysis of hybrid enzymes generated by domain shuffling between Saccharomyces cerevisiae (var diastaticus) Sta1 glucoamylase and Saccharomycopsis fibuligera Bgl1 $\beta$-glucosidase. Appl Microbiol Biotechnol 89(1):121-130

Markets and Markets (M\&M) (2020) Industrial enzyme market, Report Code: FB 2277. https://www.marketsandmarkets.com/Market-Reports/industrialenzymes-market-237327836.html. Accessed 27 Aug 2021

Marques NP, de Cassia PJ, Gomes E, da Silva R, Araújo AR, Ferreira H, Rodrigues A, Dussán KJ, Bocchini DA (2018) Cellulases and xylanases production by endophytic fungi by solid state fermentation using lignocellulosic substrates and enzymatic saccharification of pretreated sugarcane bagasse. Ind Crops Prod 122:66-75

Masutti D, Borgognone A, Scardovi F, Vaccari C, Setti L (2015) Effects on the enzymes production from different mixes of agro-food wastes. Chem Eng Trans 43:487-492

Mazzola PG, Lopes AM, Hasmann FA, Jozala AF, Penna TC, Magalhaes PO, Rangel-Yagui CO, Pessoa A Jr (2008) Liquid-liquid extraction of biomolecules: an overview and update of the main techniques. J Chem Technol Biotechnol 83(2):143-157

Mei HZ, Xia DG, Zhao QL, Zhang GZ, Qiu ZY, Qian P, Lu C (2016) Molecular cloning, expression, purification and characterization of a novel cellulase gene (Bh-EGasel) in the beetle Batocera horsfieldi. Gene 576(1):45-51

Melgosa R, Sanz MT, Solaesa ÁG, Bucio SL, Beltrán S (2015) Enzymatic activity and conformational and morphological studies of four commercial lipases treated with supercritical carbon dioxide. J Supercrit Fluids 97:51-62

Mellitzer A, Ruth C, Gustafsson C, Welch M, Birner-Grünberger R, Weis R, Purkarthofer T, Glieder A (2014) Synergistic modular promoter and gene optimization to push cellulase secretion by Pichia pastoris beyond existing benchmarks. J Biotechnol 191:187-195

Meng QS, Liu CG, Zhao XQ, Bai FW (2018) Engineering Trichoderma reesei Rut-C30 with the overexpression of egl1 at the ace 1 locus to relieve repression on cellulase production and to adjust the ratio of cellulolytic enzymes for more efficient hydrolysis of lignocellulosic biomass. J Biotechnol 285:56-63

Miao Q, Chen L, Huang L, Tian C, Zheng L, Ni Y (2014) A process for enhancing the accessibility and reactivity of hardwood kraft-based dissolving pulp for viscose rayon production by cellulase treatment. Bioresource Technol 154:109-113

Michielse CB, Hooykaas PJ, Van den Hondel CA, Ram AF (2005) Agrobacteriummediated transformation as a tool for functional genomics in fungi. Current Genet 48(1):1-17

Miletić N, Vuković Z, Nastasović A, Loos K (2009) Macroporous poly (glycidyl methacrylate-co-ethylene glycol dimethacrylate) resins-versatile immobilization supports for biocatalysts. J Mol Catal B Enzym 56(4):196-201

Mohapatra S, Padhy S, Mohapatra PKD, Thatoi H (2018) Enhanced reducing sugar production by saccharification of lignocellulosic biomass, Pennisetum species through cellulase from a newly isolated Aspergillus fumigatus. Bioresour Technol 253:262-272

Moran-Aguilar M, Costa-Trigo I, Calderón-Santoyo M, Domínguez J, AguilarUscanga M (2021) Production of cellulases and xylanases in solid-state fermentation by different strains of Aspergillus niger using sugarcane bagasse and brewery spent grain. Biochem Eng J 172:108060

Morozova W, Gusakov AV, Andrianov RM, Pravilnikov AG, Osipov DO, Sinitsyn AP (2010) Cellulases of Penicillium verruculosum. Biotechnol J 5(8):871-880

Mou H, Li B, Fardim P (2014) Pretreatment of corn stover with the modified hydrotropic method to enhance enzymatic hydrolysis. Energy Fuels 28(7):4288-4293

Mrudula S, Murugammal R (2011) Production of cellulase by Aspergillus niger under submerged and solid state fermentation using coir waste as a substrate. Braz J Microbiol 42(3):1119-1127

Mukasekuru MR, Hu J, Zhao X, Sun FF, Pascal K, Ren H, Zhang J (2018) Enhanced high-solids fed-batch enzymatic hydrolysis of sugar cane bagasse with accessory enzymes and additives at low cellulase loading. ACS Sustain Chem Eng 6(10):12787-12796

Murray P, Collins C, Grassick A, Tuohy M (2003) Molecular cloning, transcriptional, and expression analysis of the first cellulase gene (cbh2), encoding cellobiohydrolase II, from the moderately thermophilic fungus Talaromyces emersonii and structure prediction of the gene product. Biochem Biophys Res Comm 301(2):280-286

Nadar SS, Rathod VK (2019) A co-immobilization of pectinase and cellulase onto magnetic nanoparticles for antioxidant extraction from waste fruit peels. Biocatal Agric Biotechnol 17:470-479

Nair AS, Al-Battashi H, Al-Akzawi A, Annamalai N, Gujarathi A, Al-Bahry S, Dhillon GS, Sivakumar N (2018) Waste office paper: a potential feedstock for cellulase production by a novel strain Bacillus velezensis ASN1. Waste Manag 79:491-500

Nakashima K, Watanabe H, Saitoh H, Tokuda G, Azuma JI (2002) Dual cellulosedigesting system of the wood-feeding termite, Coptotermes formosanus Shiraki. Insect Biochem Mol Biol 32(7):777-784

$\mathrm{Ng}$ T, Cheung R (2011) Cellulases: types, actions, mechanism and uses. Nova Science, New York, pp 251-263

Nguyen ST, Freund HL, Kasanjian J, Berlemont R (2018) Function, distribution, and annotation of characterized cellulases, xylanases, and chitinases from CAZy. Appl Microbiol Biotechnol 102(4):1629-1637

Nussinovitch A (2010) Bead formation, strengthening, and modification. Polymer macro-and micro-gel beads: fundamentals and applications. Springer, New York, pp 27-52

Obeng EM, Adam SN, Budiman C, Ongkudon CM, Maas R, Jose J (2017) Lignocellulases: a review of emerging and developing enzymes, systems, and practices. Bioresour Bioprocess 4(1):1-22

Oberoi HS, Chavan Y, Bansal S, Dhillon GS (2010) Production of cellulases through solid state fermentation using kinnow pulp as a major substrate. Food Bioprocess Technol 3(4):528-536

Ohtoko K, Ohkuma M, Moriya S, Inoue T, Usami R, Kudo T (2000) Diverse genes of cellulase homologues of glycosyl hydrolase family 45 from the symbiotic protists in the hindgut of the termite Reticulitermes speratus. Extremophiles 4(6):343-349

Okereke O, Akanya H, Egwim E (2017) Purification and characterization of an acidophilic cellulase from Pleurotus ostreatus and its potential for agrowastes valorization. Biocatal Agric Biotechnol 12:253-259

Oliveira RDS, Bizeto MA, Camilo FF (2018a) Production of self-supported conductive films based on cellulose, polyaniline and silver nanoparticles. Carbohydr Polym 199:84-91

Oliveira SD, de Araújo Padilha CE, Asevedo EA, Pimentel VC, de Araújo FR, de Macedo GR, dos Santos ES (2018b) Utilization of agroindustrial residues 
for producing cellulases by Aspergillus fumigatus on semi-solid fermentation. J Environ Chem Eng 6(1):937-944

Olofsson J, Barta Z, Börjesson P, Wallberg O (2015) Life cycle assessment and techno-economical analysis of on-site enzyme production in 2nd generation bioethanol. The Swedish Knowledge Center For Renewable Transportation Fuels, Göteborg. https://f3centre.se/app/uploads/f3_ report_2015-05_Enzyme-production-in-2nd-generation-bioethanol150925.pdf. Accessed 27 Aug 2021

Olson DG, McBride JE, Shaw AJ, Lynd LR (2012) Recent progress in consolidated bioprocessing. Curr Opin Biotechnol 23(3):396-405

Østby H, Hansen LD, Horn SJ, Eijsink VG, Várnai A (2020) Enzymatic processing of lignocellulosic biomass: principles, recent advances and perspectives. J Ind Microbiol Biotechnol 47(9-10):623-657

Pal A, Khanum F (2011) Covalent immobilization of xylanase on glutaraldehyde activated alginate beads using response surface methodology: characterization of immobilized enzyme. Process Biochem 46(6):1315-1322

Pandey AK, Negi S (2020) Enhanced cellulase recovery in SSF from Rhizopus oryzae SN5 and immobilization for multi-batch saccharification of carboxymethylcellulose. Biocatal Agric Biotechnol 26:101656

Pandey AK, Edgard G, Negi S (2016) Optimization of concomitant production of cellulase and xylanase from Rhizopus oryzae SN5 through EVOPfactorial design technique and application in Sorghum Stover based bioethanol production. Renew Energy 98:51-56

Pant G, Prakash A, Pavani J, Bera S, Deviram G, Kumar A, Panchpuri M, Prasuna RG (2015) Production, optimization and partial purification of protease from Bacillus subtilis. J Taibah Univ Sci 9(1):50-55

Park S, Baker JO, Himmel ME, Parilla PA, Johnson DK (2010) Cellulose crystallinity index: measurement techniques and their impact on interpreting cellulase performance. Biotechnol Biofuels 3(10):1-10

Paul M, Panda G, Mohapatra PKD, Thatoi H (2020) Study of structural and molecular interaction for the catalytic activity of cellulases: an insight in cellulose hydrolysis for higher bioethanol yield. J Mol Struct 1204:127547

Perwez M, Mazumder JA, Sardar M (2019) Preparation and characterization of reusable magnetic combi-CLEA of cellulase and hemicellulase. Enzyme Microb Technol 131:109389

Pineda X, Quintana GC, Herrera AP, Sánchez JH (2020) Preparation and characterization of magnetic cellulose fibers modified with cobalt ferrite nanoparticles. Mater Chem Phys 259:122778

Podrepšek GH, Knez Ž, Leitgeb M (2019) Activation of cellulase cross-linked enzyme aggregates (CLEAs) in scCO2. J Supercrit Fluids 154:104629

Poorakbar E, Shafiee A, Saboury AA, Rad BL, Khoshnevisan K, Mamani L, Derakhshankhah H, Ganjali MR, Hosseini M (2018) Synthesis of magnetic gold mesoporous silica nanoparticles core shell for cellulase enzyme immobilization: improvement of enzymatic activity and thermal stability. Process Biochem 71:92-100

Prajapati BP, Suryawanshi RK, Agrawal S, Ghosh M, Kango N (2018) Characterization of cellulase from Aspergillus tubingensis NKBP-55 for generation of fermentable sugars from agricultural residues. Bioresour Technol 250:733-740

Premalatha N, Gopal NO, Jose PA, Anandham R, Kwon SW (2015) Optimization of cellulase production by Enhydrobacter sp. ACCA2 and its application in biomass saccharification. Front Microbiol 6(1046):1-11

Qi H (2017) Novel functional materials based on cellulose. Springer, Cham

Rabinovich M, Melnick M, Bolobova A (2002) The structure and mechanism of action of cellulolytic enzymes. Biochem Mosc 67(8):850-871

Raj K, Krishnan C (2018) High sugar yields from sugarcane (Saccharum officinarum) bagasse using low-temperature aqueous ammonia pretreatment and laccase-mediator assisted enzymatic hydrolysis. Ind Crops Prod 111:673-683

Raja S, Murty VR, Thivaharan V, Rajasekar V, Ramesh V (2011) Aqueous two phase systems for the recovery of biomolecules-a review. Sci Technol 1(1):7-16

Ravindran R, Jaiswal AK (2016) Microbial enzyme production using lignocelIulosic food industry wastes as feedstock: a review. Bioengineering 3(30): $1-22$

Raza S, Yong X, Deng J (2019) Immobilizing cellulase on multi-layered magnetic hollow particles: preparation, bio-catalysis and adsorption performances. Microporous Mesoporous Mater 285:112-119
Reinikainen T, Ruohonen L, Nevanen T, Laaksonen L, Kraulis P, Jones TA, Knowles JK, Teeri TT (1992) Investigation of the function of mutated cellulose-binding domains of Trichoderma reesei cellobiohydrolase I. Proteins 14(4):475-482

Ribeiro O, Wiebe M, Ilmén M, Domingues L, Penttilä M (2010) Expression of Trichoderma reesei cellulases CBHI and EGI in Ashbya gossypii. Appl Microbiol Biotechnol 87(4):1437-1446

Rodrigues RC, Ortiz C, Berenguer-Murcia Á, Torres R, Fernández-Lafuente R (2013) Modifying enzyme activity and selectivity by immobilization. Chem Soc Rev 42(15):6290-6307

Rodríguez-Zúñiga UF, Neto VB, Couri S, Crestana S, Farinas CS (2014) Use of spectroscopic and imaging techniques to evaluate pretreated sugarcane bagasse as a substrate for cellulase production under solid-state fermentation. Appl Biochem Biotechnol 172(5):2348-2362

Romero-Cascales I, Ros-García J, López-Roca J, Gómez-Plaza E (2012) The effect of a commercial pectolytic enzyme on grape skin cell wall degradation and colour evolution during the maceration process. Food Chem 130(3):626-631

Royvaran M, Taheri-Kafrani A, Isfahani AL, Mohammadi S (2016) Functionalized superparamagnetic graphene oxide nanosheet in enzyme engineering: a highly dispersive, stable and robust biocatalyst. Chem Eng J 288:414-422

Sadhu S, Ghosh PK, De TK, Maiti TK (2013a) Optimization of cultural condition and synergistic effect of lactose with carboxymethyl cellulose on cellulase production by Bacillus sp. isolated from fecal matter of elephant (Elephas maximus). Adv Appl Microbiol 3(3):1-9

Sadhu S, Saha P, Sen SK, Mayilraj S, Maiti TK (2013b) Production, purification and characterization of a novel thermotolerant endoglucanase (CMCase) from Bacillus strain isolated from cow dung. Springerplus 2(10):1-10

Saha K, Verma P, Sikder J, Chakraborty S, Curcio S (2019) Synthesis of chitosancellulase nanohybrid and immobilization on alginate beads for hydrolysis of ionic liquid pretreated sugarcane bagasse. Renew Energy 133:66-76

Saini R, Saini JK, Adsul M, Patel AK, Mathur A, Tuli D, Singhania RR (2015) Enhanced cellulase production by Penicillium oxalicum for bio-ethanol application. Bioresour Technol 188:240-246

Saini A, Aggarwal NK, Yadav A (2017) Cost-effective cellulase production using Parthenium hysterophorus biomass as an unconventional lignocellulosic substrate. 3 Biotech 7(12):1-11

Sakamoto K, Toyohara H (2009) Molecular cloning of glycoside hydrolase family 45 cellulase genes from brackish water clam Corbicula japonica. Comp Biochem Physiol B Biochem Mol Biol 152(4):390-396

Sandri IG, Fontana RC, Barfknecht DM, da Silveira MM (2011) Clarification of fruit juices by fungal pectinases. LWT Food Sci Technol 44(10):2217-2222

Scharf ME, Wu-Scharf D, Pittendrigh BR, Bennett GW (2003) Caste-and development-associated gene expression in a lower termite. Genome Biol 4:10-R62

Scordia D, Cosentino SL, Jeffries TW (2013) Effectiveness of dilute oxalic acid pretreatment of Miscanthus $\times$ giganteus biomass for ethanol production. Biomass Bioenergy 59:540-548

Seidl V, Gamauf C, Druzhinina IS, Seiboth B, Hartl L, Kubicek CP (2008) The Hypocrea jecorina (Trichoderma reesei) hypercellulolytic mutant RUT C30 lacks a $85 \mathrm{~kb}$ (29 gene-encoding) region of the wild-type genome. BMC Genom 99(327):1-15

Selvam K, Senbagam D, Selvankumar T, Sudhakar C, Kamala-Kannan S, Senthilkumar B, Govarthanan M (2017) Cellulase enzyme: homology modeling, binding site identification and molecular docking. J Mol Struct 1150:61-67

Seow N, Yang KL (2017) Hollow cross-linked enzyme aggregates (h-CLEA) of laccase with high uniformity and activity. Colloid Surface B Inter 151:88-94

Sepehri A, Sarrafzadeh MH, Avateffazeli M (2020) Interaction between Chlorella vulgaris and nitrifying-enriched activated sludge in the treatment of wastewater with low C/N ratio. J Clean Prod 247:119164

Shah F, Ranawat B, Dubey S, Mishra S (2021) Optimization of fermentation conditions for higher cellulase production using marine Bacillus licheniformis KY962963: an epiphyte of Chlorococcum sp. Biocatal Agric Biotechnol 29:102047 
Shajahan S, Moorthy IG, Sivakumar N, Selvakumar G (2017) Statistical modeling and optimization of cellulase production by Bacillus licheniformis NCIM 5556 isolated from the hot spring, Maharashtra, India. J King Saud Univ Sci 29(3):302-310

Sharma NK, Jha K (2010) Molecular docking: an overview. J Adv Sci Res $1(1): 67-72$

Sharma A, Tewari R, Rana SS, Soni R, Soni SK (2016) Cellulases: classification, methods of determination and industrial applications. Appl Biochem Biotechnol 179(8):1346-1380

Sheldon RA (2011a) Characteristic features and biotechnological applications of cross-linked enzyme aggregates (CLEAs). Appl Microbiol Biotechnol 92(3):467-477

Sheldon RA (2011b) Cross-linked enzyme aggregates as industrial biocatalysts. Org Process Res Dev 15(1):213-223

Shewale SD, Pandit AB (2009) Enzymatic production of glucose from different qualities of grain sorghum and application of ultrasound to enhance the yield. Carbohydr Res 344(1):52-60

Shi K, Huang X, Sun B, Wu Z, He J, Jiang P (2019) Cellulose/BaTiO 3 aerogel paper based flexible piezoelectric nanogenerators and the electric coupling with triboelectricity. Nano Energy 57:450-458

Silva A, Santos L, Valença R, Porto T, Sobrinho MDM, Gomes G, Jucá J, Santos A (2019) Cellulase production to obtain biogas from passion fruit (Passiflora edulis) peel waste hydrolysate. J Environ Chem Eng 7(6):103510

Singh RK, Tiwari MK, Singh R, Lee JK (2013) From protein engineering to immobilization: promising strategies for the upgrade of industrial enzymes. Int J Mol Sci 14(1):1232-1277

Singh S, Dikshit PK, Moholkar VS, Goyal A (2015) Purification and characterization of acidic cellulase from Bacillus amyloliquefaciens SS35 for hydrolyzing Parthenium hysterophorus biomass. Environ Prog Sustain Energy 34(3):810-818

Singh R, Kumar M, Mittal A, Mehta PK (2016) Microbial enzymes: industrial progress in 21st century. 3 Biotech 6(174):1-15

Singh J, Kapoor N, Verma A (2019) A study to evaluate the effect of phytosilver nanoparticles synthesized using Oxalis stricta plant leaf extract on extracellular fungal amylase and cellulase. Mater Today Proc 18:1342-1350

Siqueira G, Arantes V, Saddler JN, Ferraz A, Milagres AM (2017) Limitation of cellulose accessibility and unproductive binding of cellulases by pretreated sugarcane bagasse lignin. Biotechnol Biofuels 10(1):1-2

Soares-Silva I (2016) The role of the gut microbiome on chronic kidney disease. Adv Appl Microbiol 96:65-94

Sojitra UV, Nadar SS, Rathod VK (2017) Immobilization of pectinase onto chitosan magnetic nanoparticles by macromolecular cross-linker. Carbohydr Polym 157:677-685

Song X, Liu Q, Mao J, Wu Y, Li Y, Gao K, Zhang X, Bai Y, Xu H, Qiao M (2017) POT1-mediated $\delta$-integration strategy for high-copy, stable expression of heterologous proteins in Saccharomyces cerevisiae. FEMS Yeast Res 17:fox064

Spiridonov V, Liu X, Zezin S, Panova I, Sybachin A, Yaroslavov A (2020) Hybrid nanocomposites of carboxymethyl cellulose cross-linked by in-situ formed $\mathrm{Cu}_{2} \mathrm{O}$ nanoparticles for photocatalytic applications. J Organomet Chem 914:121180

Sriariyanun M, Tantayotai P, Yasurin P, Pornwongthong P, Cheenkachorn K (2016) Production, purification and characterization of an ionic liquid tolerant cellulase from Bacillus sp. isolated from rice paddy field soil. Electron J Biotechnol 19:23-28

Srinubabu G, Raju CA, Sarath N, Kumar PK, Rao JS (2007) Development and validation of a HPLC method for the determination of voriconazole in pharmaceutical formulation using an experimental design. Talanta 71(3):1424-1429

Su Z, Yang X, Shao H, Yu S (2012) Cellulase immobilization properties and their catalytic effect on cellulose hydrolysis in ionic liquid. Afr J Microbiol Res 6(1):64-70

Sugimura M, Watanabe H, Lo N, Saito H (2003) Purification, characterization, cDNA cloning and nucleotide sequencing of a cellulase from the yellow-spotted longicorn beetle, Psacothea hilaris. Eur J Biochem 270(16):3455-3460

Sui Y, Cui Y, Xia G, Peng X, Yuan G, Sun G (2019) A facile route to preparation of immobilized cellulase on olyurea microspheres for improving catalytic activity and stability. Process Biochem 87:73-82
Sukumaran RK, Singhania RR, Mathew GM, Pandey A (2009) Cellulase production using biomass feed stock and its application in lignocellulose saccharification for bio-ethanol production. Renew Energy 34(2):421-424

Swathy R, Rambabu K, Banat F, Ho SH, Chu DT, Show PL (2019) Production and optimization of high grade cellulase from waste date seeds by Cellulomonas uda NCIM 2353 for biohydrogen production. Int J Hydrog Energy 45(42):22260-22270

Syuan KY, Ai LOG, Suan TK (2018) Evaluation of cellulase and xylanase production from Trichoderma harzianum using acid-treated rice straw as solid substrate. Mater Today Proc 5(10):22109-22117

Szijártó N, Siika-Aho M, Tenkanen M, Alapuranen M, Vehmaanperä J, Réczey K, Viikari L (2008) Hydrolysis of amorphous and crystalline cellulose by heterologously produced cellulases of Melanocarpus albomyces. J Biotechnol 136(3-4):140-147

Tahir M, Saleh F, Ohtsuka A, Hayashi K (2005) Synergistic effect of cellulase and hemicellulase on nutrient utilization and performance in broilers fed a corn-soybean meal diet. Anim Sci J 76(6):559-565

Tang B, Pan H, Tang W, Zhang Q, Ding L, Zhang F (2012) Fermentation and purification of cellulase from a novel strain Rhizopus stolonifer var. reflexus TP-02. Biomass Bioenergy 36:366-372

Tapre A, Jain R (2014) Pectinases: enzymes for fruit processing industry. Int Food Res J 21(2):447-453

Teter SA, Sutton KB, Emme B (2014) Enzymatic processes and enzyme development in biorefining. Advances in biorefineries. Woodhead Publishing, Sawston, pp 199-233

Thapa S, Mishra J, Arora N, Mishra P, Li H, O' Hair J, Bhatti S, Zhou S (2020) Microbial cellulolytic enzymes: diversity and biotechnology with reference to lignocellulosic biomass degradation. Rev Environ Sci Biotechnol 19:621-648

Thomas B, Raj MC, Joy J, Moores A, Drisko GL, Sanchez CM (2018) Nanocellulose, a versatile green platform: from biosources to materials and their applications. Chem Rev 118(24):11575-11625

Thulluri C, Balasubramaniam R, Velankar HR (2021) Generation of highly amenable cellulose-I $\beta$ via selective delignification of rice straw using a reusable cyclic ether-assisted deep eutectic solvent system. Sci Rep 11(1):1-4

Tian C, Zheng L, Miao Q, Cao C, Ni Y (2014) Improving the reactivity of kraftbased dissolving pulp for viscose rayon production by mechanical treatments. Cellulose 21(5):3647-3654

Tokuda G, Watanabe H, Lo N (2007) Does correlation of cellulase gene expression and cellulolytic activity in the gut of termite suggest synergistic collaboration of cellulases? Gene 401(1-2):131-134

Transparency Market Research (TMR) (2021) Global cellulase market—global industry analysis, size, share, growth, trends, and forecast 2018-2026 Rep Id:TMRGL60753. https://www.transparencymarketresearch.com/ cellulase-market.html. Accessed 27 Aug 2021

Tsai CF, Qiu X, Liu JH (2003) A comparative analysis of two cDNA clones of the cellulase gene family from anaerobic fungus Piromyces rhizinflata. Anaerobe 9(3):131-140

Uncu ON, Cekmecelioglu D (2011) Cost-effective approach to ethanol production and optimization by response surface methodology. Waste Manag 31(4):636-643

Ungurean M, Paul C, Peter F (2013) Cellulase immobilized by sol-gel entrapment for efficient hydrolysis of cellulose. Bioprocess Biosyst Eng 36(10):1327-1338

USDA (2021) World agricultural production, United States Department of Agriculture, WAP 8-21 August 2021. https://apps.fas.usda.gov/psdon line/circulars/production.pdf. Accessed 28 Aug 2021

Vaillant F, Millan A, Dornier M, Decloux M, Reynes M (2001) Strategy for economical optimisation of the clarification of pulpy fruit juices using crossflow microfiltration. J Food Eng 48(1):83-90

Van Heiningen A (2006) Converting a kraft pulp mill into an integrated forest biorefinery. Pulp Pap Canada 107(6):38-43

Vasconcellos V, Tardioli P, Giordano R, Farinas C (2015) Production efficiency versus thermostability of (hemi) cellulolytic enzymatic cocktails from different cultivation systems. Process Biochem 50(11):1701-1709

Velmurugan $\mathrm{R}$, Incharoensakdi A (2017) $\mathrm{MgO}-\mathrm{Fe}_{3} \mathrm{O}_{4}$ linked cellulase enzyme complex improves the hydrolysis of cellulose from Chlorella sp. CYB2. Biochem Eng J 122:22-30 
Verardi A, De Bari I, Ricca E, Calabrò V (2012) Hydrolysis of lignocellulosic biomass: current status of processes and technologies and future perspectives. In: Bioethanol. pp 95-122

Verma N, Kumar V (2020) Impact of process parameters and plant polysaccharide hydrolysates in cellulase production by Trichoderma reesei and Neurospora crassa under wheat bran based solid state fermentation. Biotechnol Rep 25:e00416

Verma N, Bansal MC, Kumar V (2011) Pea peel waste: a lignocellulosic waste and its utility in cellulase production by Trichoderma reesei under solid state cultivation. BioResources 6(2):1505-1519

Verma N, Kumar V, Bansal MC (2018) Utility of Luffa cylindrica and Litchi chinensis peel, an agricultural waste biomass in cellulase production by Trichoderma reesei under solid state cultivation. Biocatal Agric Biotechnol 16:483-492

Wang J, Ding M, Li YH, Chen QX, Xu GJ, Zhao FK (2003) A monovalent anion affected multi-functional cellulase EGX from the mollusca, Ampullaria crossean. Protein Expr Purif 31(1):108-114

Wang J, Guo L, Zhang K, Wu Q, Lin J (2008) Highly efficient Agrobacteriummediated transformation of Volvariella volvacea. Bioresour Technol 99(17):8524-8527

Wang W, Zhuang X, Yuan Z, Yu Q, Qi W, Wang Q, Tan X (2012) High consistency enzymatic saccharification of sweet sorghum bagasse pretreated with liquid hot water. Bioresour Technol 108:252-257

Wang H, Pang B, Wu K, Kong F, Li B, Mu X (2014) Two stages of treatments for upgrading bleached softwood paper grade pulp to dissolving pulp for viscose production. Biochem Eng J 82:183-187

Wang Q, Liu S, Yang G, Chen J, Ji X, Ni Y (2016) Recycling cellulase towards industrial application of enzyme treatment on hardwood kraft-based dissolving pulp. Bioresour Technol 212:160-163

Wang Y, Chen D, Wang G, Zhao C, Ma Y, Yang W (2018) Immobilization of cellulase on styrene/maleic anhydride copolymer nanoparticles with improved stability against pH changes. Chem Eng J 336:152-159

Wang H, Zhai L, Geng A (2020a) Enhanced cellulase and reducing sugar production by a new mutant strain Trichoderma harzianum EUA20. J Biosci Bioeng 129(2):242-249

Wang Q, Fu X, Liu S, Ji X, Wang Y, He H, Yang G, Chen J (2020b) Understanding the effect of depth refining on upgrading of dissolving pulp during cellulase treatment. Ind Crops Prod 144:112032

Willis JD, Grant JN, Mazarei M, Kline LM, Rempe CS, Collins AG, Turner GB, Decker SR, Sykes RW, Davis MF, Labbe N (2017) The TcEG1 beetle (Tribolium castaneum) cellulase produced in transgenic switchgrass is active at alkaline $\mathrm{pH}$ and auto-hydrolyzes biomass for increased cellobiose release. Biotechnol Biofuels 10(1):1-5

Won K, Kim S, Kim KJ, Park HW, Moon SJ (2005) Optimization of lipase entrapment in Ca-alginate gel beads. Process Biochem 40(6):2149-2154

Wu W, He Q, Jiang C (2008) Magnetic iron oxide nanoparticles: synthesis and surface functionalization strategies. Nanoscale Res Lett 3:397-415

Xu J, He B, Wu B, Wang B, Wang C, Hu L (2014) An ionic liquid tolerant cellulase derived from chemically polluted microhabitats and its application in in situ saccharification of rice straw. Bioresour Technol 157:166-173

Xue DS, Liang LY, Zheng G, Lin DQ, Zhang QL, Yao SJ (2017a) Expression of Piromyces rhizinflata cellulase in marine Aspergillus niger to enhance halostable cellulase activity by adjusting enzyme-composition. Biochem Eng J 117:156-161

Xue D, Lin D, Gong C, Peng C, Yao S (2017b) Expression of a bifunctional cellulase with exoglucanase and endoglucanase activities to enhance the hydrolysis ability of cellulase from a marine Aspergillus niger. Process Biochem 52:115-122

Xue D, Jiang Y, Gong C (2019) Exogenous xylanase expression simultaneously with the indigenous cellulase to increase the cellulose hydrolysis efficiency. Int Biodeter Biodegr 140:126-132
Xue D, Yao D, Sukumaran RK, You X, Wei Z, Gong C (2020) Tandem integration of aerobic fungal cellulase production, lignocellulose substrate saccharification and anaerobic ethanol fermentation by a modified gas lift bioreactor. Bioresour Technol 302:122902

Yadav A, Ali AAM, Ingawale M, Raychaudhuri S, Gantayet LM, Pandit A (2020) Enhanced co-production of pectinase, cellulase and xylanase enzymes from Bacillus subtilis ABDR01 upon ultrasonic irradiation. Process Biochem 92:197-201

Yamaguchi H, Kiyota Y, Miyazaki M (2018) Techniques for preparation of crosslinked enzyme aggregates and their applications in bioconversions. Catalysts 8(174):1-16

Yang P, Guo L, Cheng S, Lou N, Lin J (2011) Recombinant multi-functional cellulase activity in submerged fermentation of lignocellulosic wastes. Renew Energy 36(12):3268-3272

Yarbrough JM, Mittal A, Mansfield E, Taylor LE, Hobdey SE, Sammond DW, Bomble YJ, Crowley MF, Decker SR, Himmel ME (2015) New perspective on glycoside hydrolase binding to lignin from pretreated corn stover. Biotechnol Biofuels 8(214):1-14

Yu HY, Li X (2015) Alkali-stable cellulase from a halophilic isolate, Gracilibacillus sp. SK1 and its application in lignocellulosic saccharification for ethanol production. Biomass Bioenergy 81:19-25

Zabed H, Sahu J, Boyce AN, Faruq G (2016) Fuel ethanol production from lignocellulosic biomass: an overview on feedstocks and technological approaches. Renew Sustain Energy Rev 66:751-774

Zhang YHP, Himmel ME, Mielenz JR (2006) Outlook for cellulase improvement: screening and selection strategies. Biotechnol Adv 24(5):452-481

Zhang Q, Kang J, Yang B, Zhao L, Hou Z, Tang B (2016) Immobilized cellulase on Fe O nanoparticles as a magnetically recoverable biocatalyst for the decomposition of corncob. Chin J Catal 37(3):389-397

Zhao C, Xie B, Zhao R, Fang H (2019) Microbial oil production by Mortierella isabellina from sodium hydroxide pretreated rice straw degraded by three-stage enzymatic hydrolysis in the context of on-site cellulase production. Renew Energy 130:281-289

Zheng L, Du Y, Zhang J (2001) Degumming of ramie fibers by alkalophilic bacteria and their polysaccharide-degrading enzymes. Bioresour Technol 78(1):89-94

Zhong YH, Wang XL, Wang TH, Jiang Q (2007) Agrobacterium-mediated transformation (AMT) of Trichoderma reesei as an efficient tool for random insertional mutagenesis. Appl Microb Biotechnol 73(6):1348-1354

Zhong Y, Yu H, Wang X, Lu Y, Wang T (2011) Towards a novel efficient T-DNAbased mutagenesis and screening system using green fluorescent protein as a vital reporter in the industrially important fungus Trichoderma reesei. Mol Biol Rep 38(6):4145-4151

Zhong Y, Wang X, Yu H, Liang S, Wang T (2012) Application of T-DNA insertional mutagenesis for improving cellulase production in the filamentous fungus Trichoderma reesei. Bioresour Technol 110:572-577

Zhou X, Smith JA, Oi FM, Koehler PG, Bennett GW, Scharf ME (2007) Correlation of cellulase gene expression and cellulolytic activity throughout the gut of the termite Reticulitermes flavipes. Gene 395(1-2):29-39

Zhuang J, Marchant MA, Nokes SE, Strobel HJ (2007) Economic analysis of cellulase production methods for bio-ethanol. Appl Eng Agric 23(5):679-687

\section{Publisher's Note}

Springer Nature remains neutral with regard to jurisdictional claims in published maps and institutional affiliations. 